Article

\title{
Analysis of Spatiotemporal Dynamics of the Chinese Vegetation Net Primary Productivity from the 1960s to the 2000s
}

\author{
Erping Shang ${ }^{1,2}$, Erqi Xu ${ }^{1}$, Hongqi Zhang ${ }^{1, *}$ and Fang Liu ${ }^{1}$ \\ 1 Key Laboratory of Land Surface Pattern and Simulation, Institute of Geographic Sciences and Natural \\ Resources Research, Chinese Academy of Sciences, Beijing 100101, China; shangep.15b@igsnrr.ac.cn (E.S.); \\ xueq@igsnrr.ac.cn (E.X.); liuf.08s@igsnrr.ac.cn (F.L.) \\ 2 University of Chinese Academy of Sciences, Beijing 100049, China \\ * Correspondence: zhanghq@igsnrr.ac.cn; Tel.: +86-136-2116-4004
}

Received: 26 March 2018; Accepted: 30 May 2018; Published: 1 June 2018

\begin{abstract}
Field net primary productivity (NPP) is useful in research modeling of regional and global carbon cycles and for validating results by remote sensing or process-based models. In this study, we used multiple models of NPP estimation and vegetation classification methods to study Chinese vegetation NPP characteristics, trends, and drivers using 7618 field measurements from the 1960s, 1980s, and 2000s. The values of other relevant NPP models, as well as process-based simulation and remote sensing models, were compared. Our results showed that NPP ranged from 3 to $12,407 \mathrm{gC} \cdot \mathrm{m}^{-2}$.year ${ }^{-1}$ with a mean value of $571 \mathrm{gC} \cdot \mathrm{m}^{-2} \cdot$ year $^{-1}$. Vegetation NPP gradually decreased from the southeast to the northwest. Forest, farmland, and grassland NPP was 1152, 294, and $518 \mathrm{gC} \cdot \mathrm{m}^{-2} \cdot$ year $^{-1}$, respectively. Total NPP of grassland was higher than that of farmland. Total terrestrial NPP decreased from 3.58 to $3.41 \mathrm{Pg} \mathrm{C}$ year $^{-1}$ from the 1960 s to the 2000 s, a decadal decrease of $4.7 \%$. Total NPP in forests and grasslands consistently showed a decreasing trend and

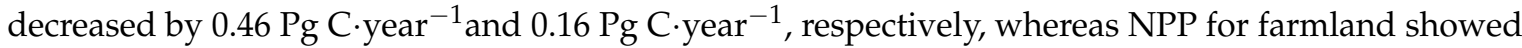
an opposite trend, with a growth of $0.45 \mathrm{Pg} \mathrm{C} \cdot$ year $^{-1}$. Our research findings filled gaps in the information regarding NPP for the entire landmass of China based on field data from a long-term time series and provide valuable information and a basis for validation analyses by remote sensing models, as well as a robust quantification of carbon estimation to anticipate future development at the national and global scale.
\end{abstract}

Keywords: NPP; field data; long-term time series; spatio-temporal analysis

\section{Introduction}

Net primary production (NPP) is the amount of organic matter produced by photosynthesis per unit of time and area, minus autotrophic respiration of vegetation [1-3]. Regional estimates of NPP are not only important variables with which to characterize vegetation activities, but also strongly influence the dynamics of the regional and global carbon cycle [4-8].

NPP at the site level can be acquired by field measurements, such as the aboveground biomass (AGB) and belowground biomass (BGB) in grasslands. However, for one researcher or a small group of researchers, this method is not feasible on a large scale as it is time-consuming, costly, and is unable to obtain full spatial coverage and a continuous long-term time-series.

With the rapid development of remote sensing and GIS technology, numerous studies at regional and global scales have been conducted concerning the method of rapidly estimating NPP using moderate-resolution satellite Normalized Difference Vegetation Index (NDVI) datasets (e.g., the Advanced Very High Resolution Radiometer (AVHRR) data and the Moderate 
Resolution Imaging Spectroradiometer (MODIS) data) [9-18] into an estimation model, such as the Carnegie-Ames-Stanford-Approach (CASA) model [19-21], the Global Production Efficiency Model (GLO-PEM) [22,23], or the Eddy Covariance-Light Use Efficiency (EC-LUE) model [24], the Atmosphere-Vegetation Interaction Model (AVIM2) [25,26], or spatial interpolation [27,28]. The remote sensing images can provide continuous, dynamic, and comprehensive land-surface information for any region on Earth $[29,30]$.

Unfortunately, many researchers avoid validating models with independent observations when estimating NPP by data-based models or remote sensing models. The results obtained by these models have differences with uncertainty [31-34], which may influence our understanding of the whole-ecosystem carbon balance [3,35-37]. On the one hand, a coarse resolution can lead to an obvious accuracy loss when modeling NPP based on the spatial heterogeneity of the data [38], especially for the AVHRR datasets with a spatial resolution of $8 \mathrm{~km}[39,40]$. On the other hand, the MODIS datasets [41,42] and Satellite Pour l'Observation de la Terre (SPOT) vegetation products [43] also have their limitations, with no data available before the year 2000, and the possibly confounding influence of cloud cover.

Reliance solely on data-based models or remote sensing models will not yield the true NPP value because of the uncertainty of these models [31-34]. Reliable data is needed for robust assessments of resource availability. Thus, it is necessary for field measurements of regional NPP because remote sensing may yield great uncertainty or time discontinuity. It is possible to use the continuous accumulation of field data by different scholars over long periods of time to show regional NPP more accurately at a large scale to resolve the problems associated with different remote sensing data and models, and provide valuable information for validation analyses by remote sensing models.

However, NPP based on field data for Chinese vegetation, which contains forest, grassland, and farmland ecosystems at the national scale, has rarely been reported. Previous studies typically focused on small scales or a single Chinese vegetation ecosystem at the large scale [44-46] and they also lack long-term time series. At the same time, robust quantification of carbon estimation is needed because, to anticipate future development, we must understand the historic growth conditions across all biomes. Thus, it is of great significance to obtain a long-term NPP series using NPP derived from field observations.

The specific objectives of this study were: (1) to compile NPP data using a Chinese vegetation classification method based on 7618 field data points between 1952 and 2010; (2) analyze its trends and drivers; and (3) to compare this estimated NPP with other relevant NPP models, as well as process-based simulation and remote sensing models.

\section{Materials and Methods}

\subsection{Chinese Vegetation Classification and Its Spatial Distribution}

China covers a broad geographical region and has a large climatic range, extending from arid to humid areas from the northwest to southeast and cold temperate to tropical climate zones from the north to south. The broad climatic gradient supports a diversity of vegetation ecosystems throughout China. We obtained the spatial distribution of different vegetation types from a vegetation map of China from the 1960s (1:4,000,000 scale) by Environmental and Ecological Science Data Center for West China, National Natural Science Foundation of China (http:/ / westdc.westgis.ac.cn) [47] (Figure S1a), the 1980s (1:1,000,000 scale) (Figure S1b) [48], and the 2000s (1:1,000,000 scale) (Figure S1c) (http: //www.geodata.cn/) [49]. According to the principles and bases of Chinese vegetation regionalization in the original maps, Chinese vegetation was classified into the forest (16 forest types) (Table S1), grassland (10 grassland types) (Table S1), and farmland (Table S1) for this study. Thus, an NPP estimate can be scaled up from the 27 vegetation types.

Until the 2000s, grassland encompassed the largest area, accounting for about $43.7 \%$ of the total vegetation area. Grasslands were mainly distributed in Northern Inner Mongolia, Xinjiang, 
Gansu, Qinghai, and the Tibet region. A total of $25.0 \%, 23.2 \%$, and $16.3 \%$ of the total grassland, respectively, were comprised of Kobresia spp. Forb in high-cold meadows; grass, Carex spp. high-cold steppes; and temperate tufted grass steppes (Figure S1c).

The second largest area was farmland (Figure S1c), accounting for about $31.93 \%$ of the total vegetation area, mainly distributed in the Eastern Plain, the Huang-Huai-Hai Plain, the Yangtze River Plain, and other regions.

Forest land (Figure S1c) encompassed about $24.4 \%$ of the total area, mainly distributed in the southern and northeast regions. The forest type is mainly needleleaf forests in subtropical zone, and broadleaf deciduous forests in temperate zone, accounting for $30.5 \%$ and $26.2 \%$ of the total area of woodland, respectively. Needleleaf forests in tropical zone, and tropical monsoon forests, accounting for less than $1 \%$ of the total forest land area, were limited to the southeastern margin of Tibet, Western Sichuan and Northwest Yunnan, with limited distribution.

\subsection{Observations Datasets}

\subsubsection{Observation Methods of Vegetation NPP}

In this study, the harvest method and biomass survey are the types of data collection procedures that originated the data, which are the most common and easiest methods, and do not require expensive and complex instruments [50-52]. These procedures can be divided into two situations. For the first procedure, aboveground and belowground farmland and grassland observations in this study were obtained using the harvesting method, where the actual biomass of green plants was physically harvested and weighed, although the data source for farmland was different from that used for grasslands and forests. In the second procedure, the forest observations were mainly based on biomass surveys obtained by destructive harvesting and weighing of tree components (e.g., stems, branches, leaves, and roots), which were subsequently scaled-up to the stand level (e.g., stems, branches, leaves, and roots were oven-dried to determine mass per unit area, $\mathrm{Mg} \cdot \mathrm{ha}^{-1}$ ). It should be noted that our stand-level biomass data of trees excluded biomass data estimated using the biomass expansion factors (BEF) method and modeling methods.

The frequencies of the data collection differed for different vegetation types. For croplands, the data covered the continuous years from 1960 to 2010 and was collected once each year. Grasslands and forest data collections rarely covered continuous observation over a long-term time scale at the same site, with observations typically occurring at uncertain times each year. This is also one of the main reasons for the periodic basis for analyses rather than continuous chronological observations. Thus, we analyzed field data from 1952 to 1970 as the same period termed "1960s", from 1980 to 1990 as 1980s, and from 2000 to 2010 as the 2000s.

\subsubsection{Data Source}

The field data on Chinese vegetation (forest, grassland) NPP were collected from peer reviewed published studies using the China National Knowledge Infrastructure database (http:/ / www.cnki. net/) [53] for Chinese-language papers (1950-2015) and the Web of Science (www.webofknowledge. com) [54] for English-language papers (1950-2015). The China Statistical Yearbooks Database (http: / / tongji.cnki.net/overseas/Dig/Dig.aspx\#) [55] was the source for farmland NPP data (1960-2010). The key words used were restricted to net primary product, NPP, net $\mathrm{CO}_{2}$ exchange, carbon flux, and China. From this literature, only studies meeting the following criteria were selected: first, the study contained the desired variable, net primary productivity (NPP); second, the study reported a certain biome (forest, grassland, or cropland) at some sites in China. The studies with incompatible methods or unclear assumptions were omitted for quality-control purposes. 


\subsubsection{Date Collection}

We extracted the desired observed site-level data, including the biomass, yield data, volume at the site level with clear latitude and longitude coordinates (during the 1960s, 1980s, and 2000s), as well as the vegetation types. In total, 7618 field data (4446 samples for farmland, 1220 samples for grassland, and 1952 samples for forest) were collected. The distribution of field samples is shown in Figure 1. These sites approximately represented all climatic zones, spanning cold humid regions, temperate humid and semi-humid regions, temperate arid and semi-arid regions, warm temperate humid and sub-humid regions, north subtropical humid regions, mid-subtropical humid regions, south subtropical humid regions, to tropical humid regions.

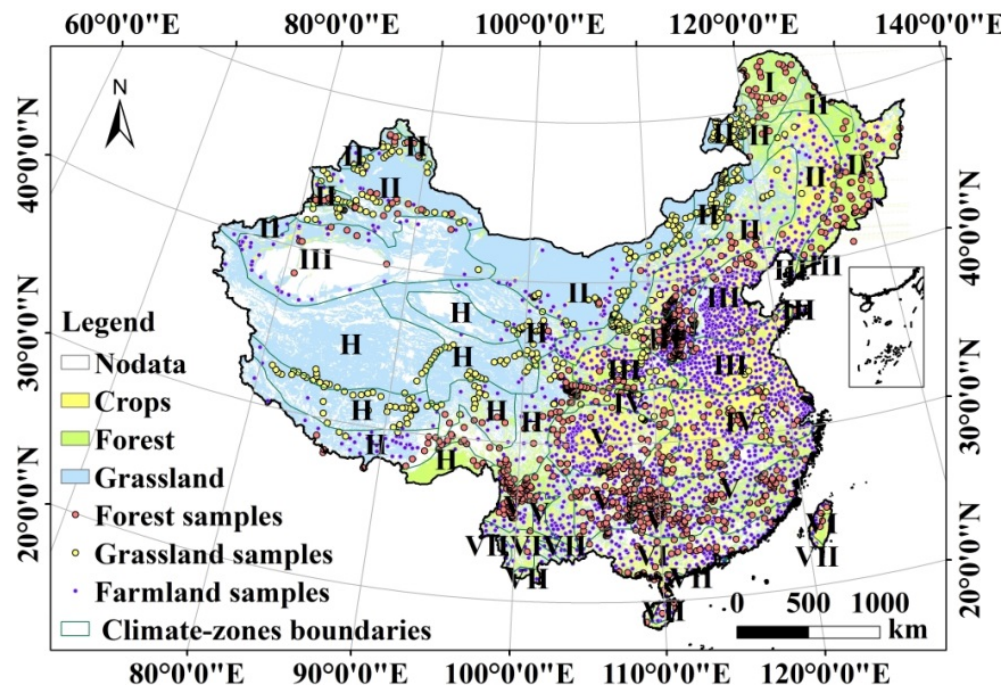

Figure 1. Distribution of samples: (1) The white areas are barren, without vegetation. (2) The data for the map was obtained from: http:/ /www.geodata.cn/ [49] (details can be seen in Section 2.1).

We used county-level crop yields (paddy, wheat, corn, legumes, potatoes, cotton, oil, and sugar) and area statistics to derive county-level net primary production (NPP). We collected 2055 samples and 2289 samples at the county level in the 1980s and 2000s, respectively, and 102 samples at the city-level and province-level were selected in the 1960s. The belowground farmland NPP estimates were obtained using a standard factor that is described in detail in Section 2.3.1.

A total of 1220 grassland biomass samples was obtained at the site-level. In the 1960s, 117 samples with fresh weight data from each sampling site located in all northern provinces and part of the southern provinces (e.g., Guizhou, Sichuan, Yunnan, and Guangxi) were obtained [56]. A total of 656 and 447 samples from papers published in the 1980s and 2000s were obtained, respectively, with records of aboveground and belowground biomass and forage-yield field data obtained from sites widely distributed in tropical, subtropical, warm temperate, temperate, and cold temperate zones. These data reflect the spatial distribution pattern of China's grassland biomass and NPP.

The data on forest NPP included samples from over 1952 plots. In detail, the 1960s data included the initial vegetation records for 209 plots, of which 30 plots included forest areas and volume data at the province-level, 160 plots included volume data for four species of age-class accumulation in 10 counties in Southeastern Guizhou, 14 plots included volume data (dominant tree species) in Xinjiang, and five NPP plots. In the 1980s, data included 1024 forest plots (trunk biomass, branch biomass, leaf biomass, and root biomass) with precise spatial geo-coordinates collected by Luo [57]. In the 2000s, we obtained the initial vegetation biomass and forest age data of 147 plots from the literature, including 572 samples contained NPP in the Global Primary Production Data Initiative (GPPDI) (https:/ / daac.ornl.gov/cgi-bin/dataset_lister.pl?p=13) [58]. 


\subsection{Estimation of NPP}

\subsubsection{Farmland NPP}

The farmland NPP was estimated from eight kinds of crop production data using the following equation [59-61]:

$$
\mathrm{NPP}=\sum_{\mathrm{i}=1}^{\mathrm{N}} \frac{\mathrm{Y}_{\mathrm{i}} \times\left(1-\mathrm{Mc}_{\mathrm{i}}\right) \times 0.45 \frac{\mathrm{gC}}{\mathrm{g}}}{\mathrm{HI}_{\mathrm{i}} \times f_{A G}} / \sum_{\mathrm{i}=1}^{\mathrm{N}} \mathrm{A}_{\mathrm{i}},
$$

where NPP refers to the total farmland NPP $\left(\mathrm{gC} \cdot \mathrm{m}^{-2} \cdot \mathrm{year}^{-1}\right), \mathrm{Y}_{\mathrm{i}}$ is the crop production $(\mathrm{t}), \mathrm{Mc}_{\mathrm{i}}$ is the water content of the crop harvest (\%) (Table S2), $\mathrm{HI}_{\mathrm{i}}$ is the crop harvest index (economic production and the ratio of plant dry weight above ground.) (Table S2) [59-61], $A_{i}$ is the crop harvest area $\left(\mathrm{hm}^{2}\right)$, 0.45 is the carbon conversion coefficient [61,62], and $f_{A G}$ refers to the fraction of the aboveground biomass to the total biomass (Table S2) [59,63-66]. Different crops had different parameters, which can be seen in Table S2.

\subsubsection{Grassland NPP}

A series of grassland NPP estimation algorithms from biomass measurements are described [67-69], where the assumptions may only apply in certain sub-biomes. In this study, grassland NPP was estimated from biomass data using two separate equations. When the biomass data contained the aboveground biomass (AGB) and belowground biomass (BGB), we used the following equation:

$$
\mathrm{NPP}=\left(\text { Biomass }_{\mathrm{up}}+\text { Biomass }_{\text {down }}\right) \times 0.45,
$$

where NPP refers to the total grassland NPP $\left(\mathrm{gC} \cdot \mathrm{m}^{-2} \cdot \mathrm{year}^{-1}\right)$, Biomass $_{\mathrm{up}}$ is the dry matter yield AGB $\left(\mathrm{g} \cdot \mathrm{m}^{-2}\right)$, and Biomass ${ }_{\text {down }}$ is the dry matter yield BGB $\left(\mathrm{g} \cdot \mathrm{m}^{-2}\right)$, and 0.45 is the carbon conversion coefficient [61].

When only the AGB data was available, the formula was calculated based on the ratio coefficient of AGB and BGB, which mainly used the different ratios between AGB and BGB for all grassland types according to the published literature which relied on field data (Table S3). The formula is as follows [70]:

$$
\mathrm{NPP}=\mathrm{Bg} \times \mathrm{Sbn} \times(1+\mathrm{Sug}),
$$

where NPP refers to the total grassland NPP $\left(\mathrm{gC} \cdot \mathrm{m}^{-2} \cdot \mathrm{year}^{-1}\right), \mathrm{Bg}$ is the dry matter yield above-ground $\left(\mathrm{g} \cdot \mathrm{m}^{-2}\right)$ (Table S3); Sbn is the conversion factor from dry matter yield to NPP $\left(\mathrm{g} \cdot \mathrm{g}^{-1} \cdot \mathrm{C}\right)$ (Table S3); and Sug is the ratio of below-to above-ground biomass (Table S3) [70]. Different grassland types had different parameters, which can be seen in Table S3.

To obtain the dry matter values (Bg), first, it was necessary to calculate the amount of fresh grass and the amount of grass production data in accordance with a unified conversion factor for the dry matter content. The fresh grass hay equivalent ratio of the ten different types of grass (Rfd) is shown in Table S3 [70-73], whereas in the 1980s and 2000s, the percentage of water content (PWC) in the dried hay was $15 \%$ [61], and the aboveground biomass (dry matter content) (Bg) was obtained by grass yield minus moisture content in hay.

\subsubsection{Forest NPP}

The forest NPP was estimated from the biomass data (i.e., the dataset in the 2000s) using the following equation [61,72]:

$$
\begin{gathered}
\mathrm{NPP}_{\mathrm{T}}=\mathrm{B} /(\mathrm{c} \times \mathrm{A}+\mathrm{d} \times \mathrm{B}), \\
\mathrm{NPP}_{\mathrm{L}}=\frac{1}{\mathrm{e} / \mathrm{B}+\mathrm{f}}
\end{gathered}
$$


where $\mathrm{NPP}_{\mathrm{T}}$ is the tree $\mathrm{NPP}\left(\mathrm{gC} \cdot \mathrm{m}^{-2} \cdot \mathrm{year}^{-1}\right), \mathrm{NPP}_{\mathrm{L}}$ is annual litterfall per unit area $\left(\mathrm{gC} \cdot \mathrm{m}^{-2} \cdot\right.$ year $\left.^{-1}\right), \mathrm{B}$ is biomass $\left(\mathrm{gC} \cdot \mathrm{m}^{-2} \cdot \mathrm{year}^{-1}\right), \mathrm{A}$ is age; and $\mathrm{c}, \mathrm{d}, \mathrm{e}$, and $\mathrm{f}$ are the corresponding forest type constants (Table S4) [74-76].

There are two methods for calculating the biomass. The first method is that calculating from the sum of the parts [77]:

$$
\mathrm{B}=\mathrm{B}_{\mathrm{S}}+\mathrm{B}_{\mathrm{b}}+\mathrm{B}_{1}+\mathrm{B}_{\mathrm{r}}
$$

where $\mathrm{B}$ is the tree biomass $\left(\mathrm{gC} \cdot \mathrm{m}^{-2} \cdot\right.$ year $\left.^{-1}\right) ; \mathrm{B}_{\mathrm{S}}, \mathrm{B}_{\mathrm{b}}, \mathrm{B}_{\mathrm{l}}$, and $\mathrm{B}_{\mathrm{r}}$ represent the trunk biomass $\left(\mathrm{gC} \cdot \mathrm{m}^{-2} \cdot\right.$ year $\left.^{-1}\right)$, branch biomass $\left(\mathrm{gC} \cdot \mathrm{m}^{-2} \cdot \mathrm{year}^{-1}\right)$, leaf biomass $\left(\mathrm{gC} \cdot \mathrm{m}^{-2} \cdot \mathrm{year}^{-1}\right)$, and root biomass $\left(\mathrm{gC} \cdot \mathrm{m}^{-2} \cdot\right.$ year $\left.^{-1}\right)$ in year i, respectively. The method was suitable for estimates of forests in the 1980s, for which the dataset included biomass measurements for parts of the forest. However, some of the samples only included the volume and ages (i.e., 1960s), and we first used the following formula to estimate the biomass:

$$
\mathrm{B}=\mathrm{V} /(\mathrm{a}+\mathrm{b} * \mathrm{~V}),
$$

where $B$ is the biomass $\left(\mathrm{gC} \cdot \mathrm{m}^{-2} \cdot \mathrm{year}^{-1}\right), \mathrm{V}$ is the volume of the tree $\left(\mathrm{m}^{3} \cdot \mathrm{hm}^{-2}\right)$, and a and $\mathrm{b}$ were the constants (Table S4) [74].

Thus, the forest NPP, which is the estimation of annual growth and annual litterfall in the forest community, is calculated using the following formula:

$$
\mathrm{NPP}=\mathrm{NPP}_{\mathrm{T}}+\mathrm{NPP}_{\mathrm{L}}
$$

where NPP is the forest NPP $\left(\mathrm{gC} \cdot \mathrm{m}^{-2} \cdot \mathrm{year}^{-1}\right), \mathrm{NPP}_{\mathrm{T}}$ is the tree $\left.\mathrm{NPP} \mathrm{gC} \cdot \mathrm{m}^{-2} \cdot \mathrm{year}^{-1}\right)$, and $\mathrm{NPP}_{\mathrm{L}}$ is the annual litterfall per unit area $\left(\mathrm{gC} \cdot \mathrm{m}^{-2} \cdot \mathrm{year}^{-1}\right)$.

\subsection{The Method of Scaling-Up Using NPP Classification Methods}

To investigate the differences in NPP values among different regions, we used site-scale NPP estimates for large-scale estimates based on Chinese vegetation types. Chinese vegetation has horizontal and vertical distribution patterns, which are divided into forest, grassland, and farmland types, and are influenced by climate (e.g., temperature and precipitation), topography, soil types, and management history [78,79]. In this study, the Chinese vegetation could be divided into forest, grassland, and farmland. Consequently, the process of scale-up is significant, presenting a challenge for using site-scale NPP estimates for large-scale estimates.

Forest sites represented all climatic zones, spanning cold temperate to tropical zones, which is consistent with horizontal and vertical distribution patterns [78,79]. Forests were divided into sixteen types, corresponding to climate regions (Table S1, Figure S1). Each site can be identified based on the sub-type to which it belongs. We can then obtain the average NPP of the same forest type sub-class, multiplying this value by the area of the corresponding forest type can calculate the corresponding forest type total NPP. Thus, the calculated total NPP at the national scale by the mean NPP method, e.g., the total NPP for the different forest components in China's forest ecosystems, was analyzed according to the average NPP of sixteen forest types and their corresponding areas for each type $[48,80]$, which can be obtained from the spatial distribution map of the forest types.

The method of estimating grassland NPP from site-scale to large-scale is similar to the forest method. For the statistical and comparative analyses, the Chinese grasslands were divided into ten types (Table S1, Figure S1). The total NPP of grassland could be calculated from ten grassland types and their corresponding areas by the mean NPP method.

Farmland NPP estimates differ from forests and grasslands at the national scale. Since farmland data are mainly derived from national statistics, including data for each county, the total farmland NPP can be easily calculated based on the NPP at county-level scales and its corresponding area. The results obtained by this method are also the main sources of the results of other model estimation methods. 


\subsection{Process-Based and Remote Sensing Models}

There are process models and remote sensing models to simulate NPP. In our study, the methods of estimating NPP included the Boreal Ecosystem Productivity Simulator (BEPS) model, the BIOME BioGeochemical Cycles (BIOME-BGC) model, the Carbon Exchange between Vegetation, Soil and Atmosphere model (CEVSA) model, the Terrestrial Ecosystem Model (TEM) model, and the Integrated Biosphere Simulator (IBIS) model. The remote sensing models included the CASA, the EC-LUE, the GLO-PEM, and the MOD17 models. The features of these models have been well-documented in the papers [81-83].

\subsection{Statistical Analysis}

Statistical characteristics of NPP, including the maximum, minimum, mean, and the percentile values (25th, 50th, 75th) in three periods were calculated based on multiple sites in the same periods by SPSS software (version 18.0) [84]. The analysis of NPP distribution was performed using ArcGIS 10.1 software[85].

\section{Results}

\subsection{Statistical Characteristics of NPP in Different Periods}

Within the 7618 field-measured samples published from the 1960s to 2000s, Chinese vegetation $\mathrm{NPP}$ ranged from 3 to $12,407 \mathrm{gC} \cdot \mathrm{m}^{-2} \cdot \mathrm{year}^{-1}$ with an average value of $571 \mathrm{gC} \cdot \mathrm{m}^{-2} \cdot \mathrm{year}^{-1}$. Among them, $63.2 \%$ of the samples were distributed from $200 \mathrm{gC} \cdot \mathrm{m}^{-2} \cdot$ year $^{-1}$ to $1500 \mathrm{gC} \cdot \mathrm{m}^{-2} \cdot$ year $^{-1}$.

Remarkable differences in NPP were found in different vegetation types (Figure 2). The mean of the NPP for forest, grassland, and farmland in the 1960s, 1980s, and 2000s decreased in turn. The forest NPP had the highest value, with a mean value of $1128 \mathrm{gC} \cdot \mathrm{m}^{-2} \cdot \mathrm{year}^{-1}$ ranging from 600 to $12,407 \mathrm{gC} \cdot \mathrm{m}^{-2} \cdot$ year $^{-1}$. The grassland NPP ranged from 3 to $5663 \mathrm{gC} \cdot \mathrm{m}^{-2} \cdot \mathrm{year}^{-1}$. The forest and grassland both decreased first from the 1960s to the 1980s and increased from the 1980s to the 2000s. Farmland ranged from 4 to $8624 \mathrm{gC} \cdot \mathrm{m}^{-2} \cdot \mathrm{year}^{-1}$, and increased from the $1960 \mathrm{~s}$ to the 2000s. In all, a decrease in forest NPP and an increase both in grassland and farmland NPP from the 1960s to 2000s was observed.

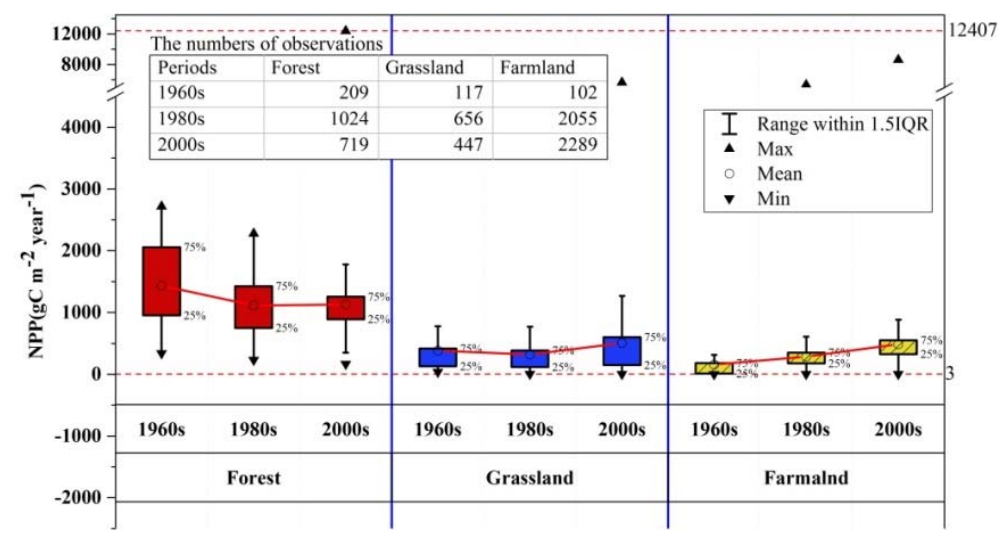

Figure 2. The statistical characteristics of sample point NPP observations.

\subsection{Distribution of China's Vegetation NPP in the 2000s}

\subsubsection{Summary Analysis}

In the 2000s, the mean and total NPP of Chinese vegetation was $596 \mathrm{gC} \cdot \mathrm{m}^{-2} \cdot \mathrm{year}^{-1}$ and 3.41 Pg C year $^{-1}$, respectively. The vegetation NPP in southern China was larger compared with that in Northern China (Figure 3). The higher NPP was mainly distributed in the southern tropical humid 
region and the southeastern edge of the Tibetan Plateau, especially in Western Yunnan, Central Sichuan, the southeastern margin of Tibet, Southern Zhejiang, Northern Guangdong, and most parts of Hainan and Fujian, where the NPP was more than $900 \mathrm{gC} \cdot \mathrm{m}^{-2} \cdot$ year $^{-1}$, mainly in forest types, grasslands, meadows, and three season rice because of the good hydrothermal and heat conditions. The NPP of Guangxi, Southern Guangdong, the Huang-Huai-Hai plain (HHH), Jiangsu, and Zhejiang were 500 to $800 \mathrm{gC} \cdot \mathrm{m}^{-2} \cdot$ year $^{-1}$, mainly in crops harvested two or three times per year, or three times every two years. The lower NPP occurred in the temperate tufted grass steppes, temperate tufted low grass. and nano-semi-shrub desert steppes grass and Carex spp. high-cold steppes, and one or two season crops or drought crops with poor water conditions, which were mainly distributed in the eastern and southern part of Inner Mongolia, the northwest of Tibet, and part of Xinjiang where the NPP was below $200 \mathrm{gC} \cdot \mathrm{m}^{-2} \cdot$ year $^{-1}$.
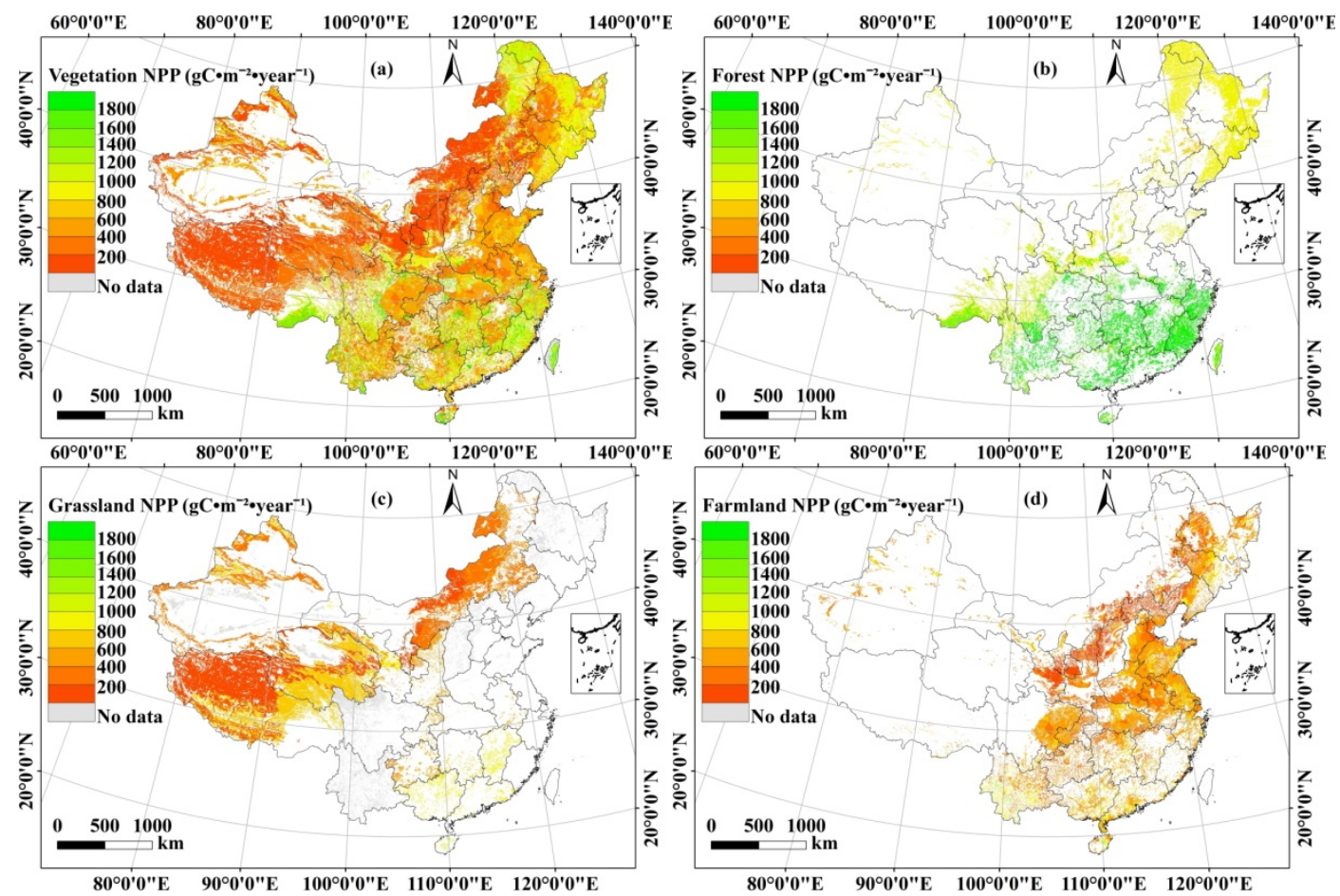

Figure 3. The distribution of vegetation NPP in the 2000s: (a) vegetation NPP in the 2000s; (b) forest NPP in the 2000s; (c) grassland NPP in the 2000s; and (d) farmland NPP in the 2000s.

\subsubsection{Distribution of the Individual Vegetation Type in the 2000s}

Remarkable differences in NPP were found in the three vegetation types. The average $\mathrm{NPP}$ values of forest, farmland, and grassland were $1152 \mathrm{gC} \cdot \mathrm{m}^{-2} \cdot \mathrm{year}^{-1}, 518 \mathrm{gC} \cdot \mathrm{m}^{-2} \cdot \mathrm{year}^{-1}$, and $294 \mathrm{gC} \cdot \mathrm{m}^{-2} \cdot$ year $^{-1}$, respectively. The NPP values from forests were higher in the east and south than that in the west and north. The average NPP for Tropical monsoon forests was the highest with the value of $2019 \mathrm{gC} \cdot \mathrm{m}^{-2}$.year ${ }^{-1}$, followed by broadleaf deciduous forests in the subtropical zone, broadleaf evergreen and deciduous mixed forests in the subtropical zone, broadleaf evergreen forests in the subtropical zone, Sclerophyllus broadleaf evergreen forests in the subtropical zone, tropical rain forests, bamboo forests and scrubs in the subtropical and tropical zones, for which NPP was above $1500 \mathrm{gC} \cdot \mathrm{m}^{-2} \cdot \mathrm{year}^{-1}$. The lowest NPP was in Microphyllous deciduous woodlands in the temperate zone, with an average value of approximately $906 \mathrm{gC} \cdot \mathrm{m}^{-2} \cdot$ year $^{-1}$.

Approximately $58 \%$ of the farmland sample NPP values were within 300 to $600 \mathrm{gC} \cdot \mathrm{m}^{-2} \cdot \mathrm{year}^{-1}$. The distribution of crop NPP increased from northwest to southeast. NPP in Hainan, Guangdong, Fujian, and Zhejiang were higher, with values above $600 \mathrm{gC} \cdot \mathrm{m}^{-2} \cdot$ year $^{-1}$, and approximately $5 \%$ of 
the county's crop NPP was above $1000 \mathrm{gC} \cdot \mathrm{m}^{-2} \cdot \mathrm{year}^{-1}$, for which two or three plantings a year were normal, given the steady water supply, constant sun, and rich soil. The lower NPP values occurred in Inner Mongolia, Shaanxi, Xinjiang, and Shanxi, with values less than $200 \mathrm{gC} \cdot \mathrm{m}^{-2} \cdot \mathrm{year}^{-1}$ in one or two-season crops or drought crops.

Grassland NPP was in the range of 3 to $5663 \mathrm{gC} \cdot \mathrm{m}^{-2} \cdot \mathrm{year}^{-1}$ in the eastern region was generally higher than that in the central and western regions. The largest NPP was in Grass, Carex, and forb swamp meadows with an average NPP of $1219 \mathrm{gC} \cdot \mathrm{m}^{-2} \cdot \mathrm{year}^{-1}$, which were located in Yunnan and Guangxi, and Eastern Tibet. The NPP for steppes and meadows were lower, especially in the temperate tufted low grass and nano-semi-shrub desert steppes, and grass and Carex spp. high-cold steppes with values of 131 and $143 \mathrm{gC} \cdot \mathrm{m}^{-2} \cdot$ year $^{-1}$, respectively. These were mainly distributed in western China in the Alashan Desert area, the Ma Zongshan-Nuo Min Gobi shrubs, and semi-shrub desert areas.

However, the distribution of the total NPP was different from the average of NPP. The total NPP in the forest was $57.5 \%$ of the total Chinese vegetation NPP. This was followed by grassland, which accounts for $24.3 \%$ of the total NPP. The lowest total NPP occurred in farmland, which accounts for $18.1 \%$. The total NPP of the forest was approximately 3.2 times that of farmland. Grassland total NPP was higher than farmland because the total area of grassland $\left(281.98 \times 10^{4} \mathrm{~km}^{2}\right)$ was much greater than the total cropland area $\left(119.31 \times 10^{4} \mathrm{~km}^{2}\right)$. The highest total NPP in the forest was not only due to the area, but also because the per unit area NPP of the forest was much larger than that of cropland and grassland.

\subsection{Temporal and Spatial Trends in Average NPP and Total NPP}

\subsubsection{Summary Analysis}

From the 1960s to the 2000s, the Chinese total NPP fell from 3.58 to $3.41 \mathrm{Pg} \mathrm{C} \cdot$ year $^{-1}$, with a decrease of $4.7 \%$. There was an overall decrease, but a partial increase in the spatial trend (Figure $4 a$, Table 1). The higher decline of NPP was mainly distributed in the northern part of Southwest China, along the Yangtze River Middle Plains (YR) with a decrease above $60 \%$, followed by the northern part of Inner Mongolia, the Changbai mountain forest area in Northeastern China, and the Eastern Liaoning Plain, with a decline below $20 \%$. However, NPP increased by more than $60 \%$ in the central area of $\mathrm{HHH}$, the Northern YR, the Sichuan Basin (SCB), and the southeastern margin of the Tibetan Plateau. NPP changed directions in the period of the 1960s-1980s and the 1980s-2000s, and the reduction of the former was higher than the increase of the latter (Table 1).

The two periods (1960s-1980s and 1980s-2000s) showed opposite trends, and the decrease in the previous period was greater than the increase in the latter period. During the period of the 1960s-1980s (Figure 4b, Table 1), the total NPP dropped by $21.2 \%$. The area of forests and grasslands has decreased significantly by the deforestation which, in turn, has led to a decline in NPP per unit area of vegetation, leading to a decrease in total NPP. The decrease of the average annual precipitation and the average annual solar radiation may also lead to a decrease in NPP. The significant decline in NPP was observed at YR South China and Southwest China, with reductions of more than $60 \%$, followed by the high-cold region of the northwestern area of the Tibetan Plateau, the Ganxin Region, Northern Inner Mongolia, and scattered distribution areas in YR and the southwestern region, with the decrease between $20 \%$ and $60 \%$. During the period of the 1980s to 2000s (Figure 4c, Table 1), the total and average NPP increased by $0.59 \mathrm{Pg} \mathrm{C} \cdot$ year $^{-1}$ and $71 \mathrm{gC} \cdot \mathrm{m}^{-2} \cdot$ year $^{-1}$, which was significantly increased by $21.0 \%$. The increasing temperatures in Northeast China and the Qinghai-Tibet Plateau, the increasing precipitation in Northwest China and increasing solar radiation in East China and South China may all promote vegetation growth to increase NPP. The NPP increased by more than $60 \%$ mainly in $\mathrm{HHH}$, Western and Northwestern Tibet Plateau, and Northern China. This was followed by the southeastern margin of the Tibetan Plateau, SCB, and YR with growth between $20 \%$ and $60 \%$. However, a small portion in the south of Northeast China, Southwest China, and south of YR fell by $20-60 \%$. 


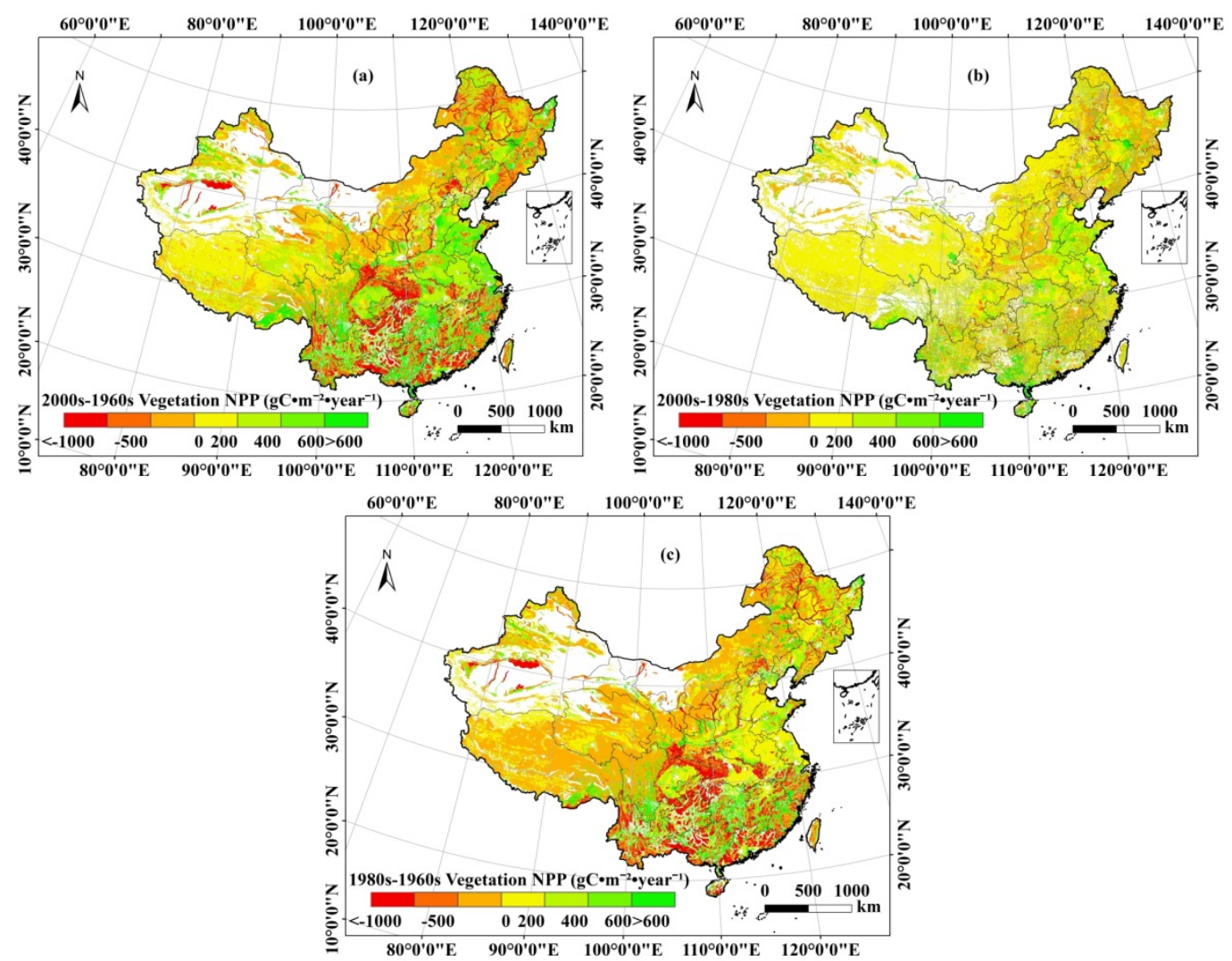

Figure 4. Trends of NPP from the 1960s to 2000s: (a) variation in the vegetation NPP from the 1960s to the 2000s; (b) variation in the vegetation NPP from the 1960s to the1980s; and (c) variation in the vegetation NPP from the 1980s to the 2000s.

Table 1. The total and mean NPP of Chinese vegetation in 1960s, 1980s, and 2000s.

\begin{tabular}{|c|c|c|c|}
\hline Time Period & Vegetation Area $\left(10^{4} \mathrm{~km}^{2}\right)$ & Mean NPP $\left(\mathrm{gC} \cdot \mathrm{m}^{-2} \cdot\right.$ year $\left.^{-1}\right)$ & Total NPP (Pg C. year $\left.^{-1}\right)$ \\
\hline $1960 \mathrm{~s}$ & 612.24 & 584 & 3.58 \\
\hline 1980s & 535.92 & 525 & 2.82 \\
\hline $2000 s$ & 571.43 & 596 & 3.41 \\
\hline
\end{tabular}

\subsubsection{Trends in Individual Vegetation Types}

The NPP trends of the three vegetation types were different. From the 1960s to the 2000s, the trends in forest and grassland were consistent with Chinese vegetation NPP, whereas the trend for farmland NPP was in the opposite direction (Figures 5 and 6). In particular, the total NPP of forest and grassland decreased by $0.46 \mathrm{Pg} \mathrm{C} \cdot$ year $^{-1}$ and $0.16 \mathrm{Pg} \mathrm{C} \cdot$ year $^{-1}$, by nearly $-4.5 \%$ and $0.8 \%$ per year, respectively. However, farmland increased by $0.45 \mathrm{Pg} \mathrm{C} \cdot$ year $^{-1}$, with a higher growth rate of $18 \mathrm{gC} \cdot \mathrm{m}^{-2} \cdot \mathrm{year}^{-1}$, but with a lower NPP and areas. Comparing the NPP in the two periods, the 1960s-1980s and the 1980s-2000s, the forest and grassland NPP first decreased and then increased, but farmland NPP showed a steady increase.

In the 1960s-1980s, the total NPP of woodland decreased from 2.42 to $1.71 \mathrm{Pg} \mathrm{C} \cdot$ year $^{-1}$, with an average annual decrease of $0.0355 \mathrm{Pg} \mathrm{C} \cdot$ year $^{-1}$ and $6 \mathrm{gC} \cdot \mathrm{m}^{-2} \cdot$ year $^{-1}$, and with a decline of $5.5 \%$ (Figure 5). The NPP decreased more in the south than in the north (Figure 6d), where the decline was over $40 \%$, mainly in the needleleaf forests in cold-temperate zone and on mountains in temperate zone, broadleaf deciduous forests in temperate zone, and broadleaf deciduous forests in subtropical zone. The total grassland NPP also decreased from 0.99 to $0.77 \mathrm{Pg} \mathrm{C}_{\text {year }}{ }^{-1}$, with a percentage decline of $1.1 \%$, which means that there was an average annual decrease of $0.011 \mathrm{Pg} \mathrm{C} \cdot \mathrm{year}^{-1}$ and $1.0 \mathrm{gC} \cdot \mathrm{m}^{-2} \cdot \mathrm{year}^{-1}$. 
All eight types of grassland were in a decreasing trend, with an average decline of 18.7\%. The larger change mainly occurred in the grass, and Carex and forb swamp meadows, which were located in Tibet, Guangdong, Guangxi, and Inner Mongolia (Figure 6). Farmland total NPP changed differently from that of forests and grasslands and increased from 0.17 to $0.34 \mathrm{Pg} \mathrm{C} \cdot$ year $^{-1}$. The average annual growth was $0.0085 \mathrm{Pg} \mathrm{C} \cdot$ year $^{-1}$ and $7 \mathrm{gC} \cdot \mathrm{m}^{-2} \cdot$ year $^{-1}$, with a growth of $5.2 \%$. The farmland NPP in Liaoning, Shandong, Henan, and Anhui Provinces grew faster (Figure 6f).

In the periods of the 1980s-2000s, the total NPP of forest, farmland, and grassland all increased. Forest NPP increased from $1.71 \mathrm{Pg} \mathrm{C} \cdot$ year $^{-1}$ to $1.96 \mathrm{Pg} \mathrm{C}$ year $^{-1}$ with growth of $0.7 \%$, representing a growth rate of $0.01 \mathrm{Pg} \mathrm{C} \cdot$ year $^{-1}$ and $1 \mathrm{gC} \cdot \mathrm{m}^{-2} \cdot$ year $^{-1}$. Except for some areas of Heilongjiang, the forest NPP of southern China had increased little, especially the forests of the type needleleaf forests in the temperate zone, and needleleafforests on mountains in a subtropical tropical zone, and broadleaf deciduous forests in a subtropical zone increased more, with a growth of $20 \%$ and $30 \%$, respectively (Figure $6 \mathrm{~g}$ ). Grassland total NPP increased from 0.77 to $0.83 \mathrm{Pg} \mathrm{C} \cdot$ year $^{-1}$ with the growth of $0.39 \%$, and the average growth per year was $0.003 \mathrm{Pg} \mathrm{C} \cdot$ year $^{-1}$ and $1 \mathrm{gC} \cdot \mathrm{m}^{-2} \cdot$ year $^{-1}$ with an average growth of $14.2 \%$. The highest increase was observed in grass and Carex spp. on high-cold steppes, followed by temperate tufted low grass, nano-semi-shrub desert steppes, and Kobresia spp., forb high-cold meadows, with a growth of approximately $13.0 \%$ (Figure $6 \mathrm{~h}$ ). Farmland NPP increased from $0.34 \mathrm{Pg} \mathrm{C}$ year $^{-1}$ to $0.62 \mathrm{Pg} \mathrm{C} \cdot$ year $^{-1}$, with a growth of $4.2 \%$, representing a growth rate of $0.014 \mathrm{Pg} \mathrm{C} \cdot$ year $^{-1}$ and $11 \mathrm{gC} \cdot \mathrm{m}^{-2} \cdot$ year $^{-1}$. The speed of farmland NPP increase was at a greater rate in Guangdong, Guangxi, Xinjiang, Yunnan, and Shandong than other regions (Figure 6i).
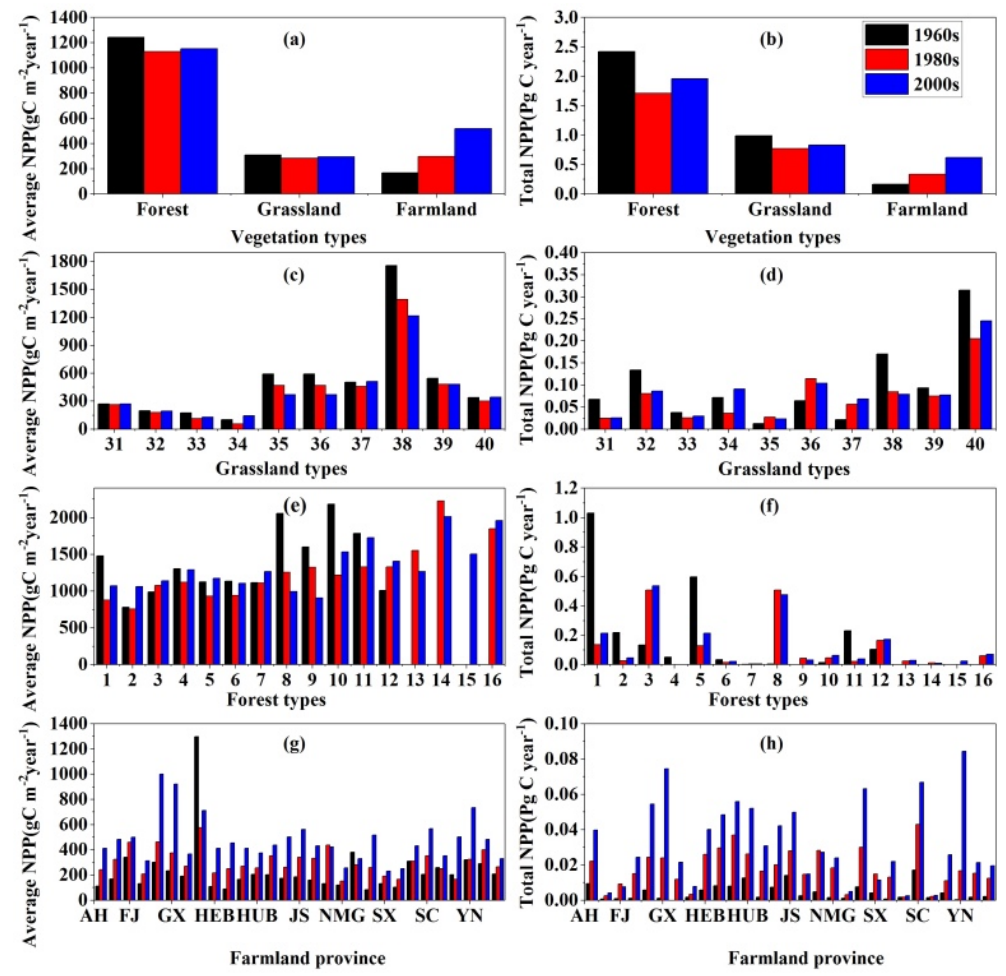

Figure 5. NPP Changes of different vegetation types from the 1960s to 2000s: (a) average vegetation NPP; (b) total vegetation NPP; (c) average NPP in different forest types; (d) total NPP in different forest types; (e) average NPP in different grassland types; (f) total NPP in different grassland types; (g) average NPP in different farmland provinces; and (h) total NPP in different farmland provinces. The meaning of the id numbers are listed for the forest (1-16) (Table S1), grassland (31-40) (Table S1), and farmland (Table S5), respectively. 

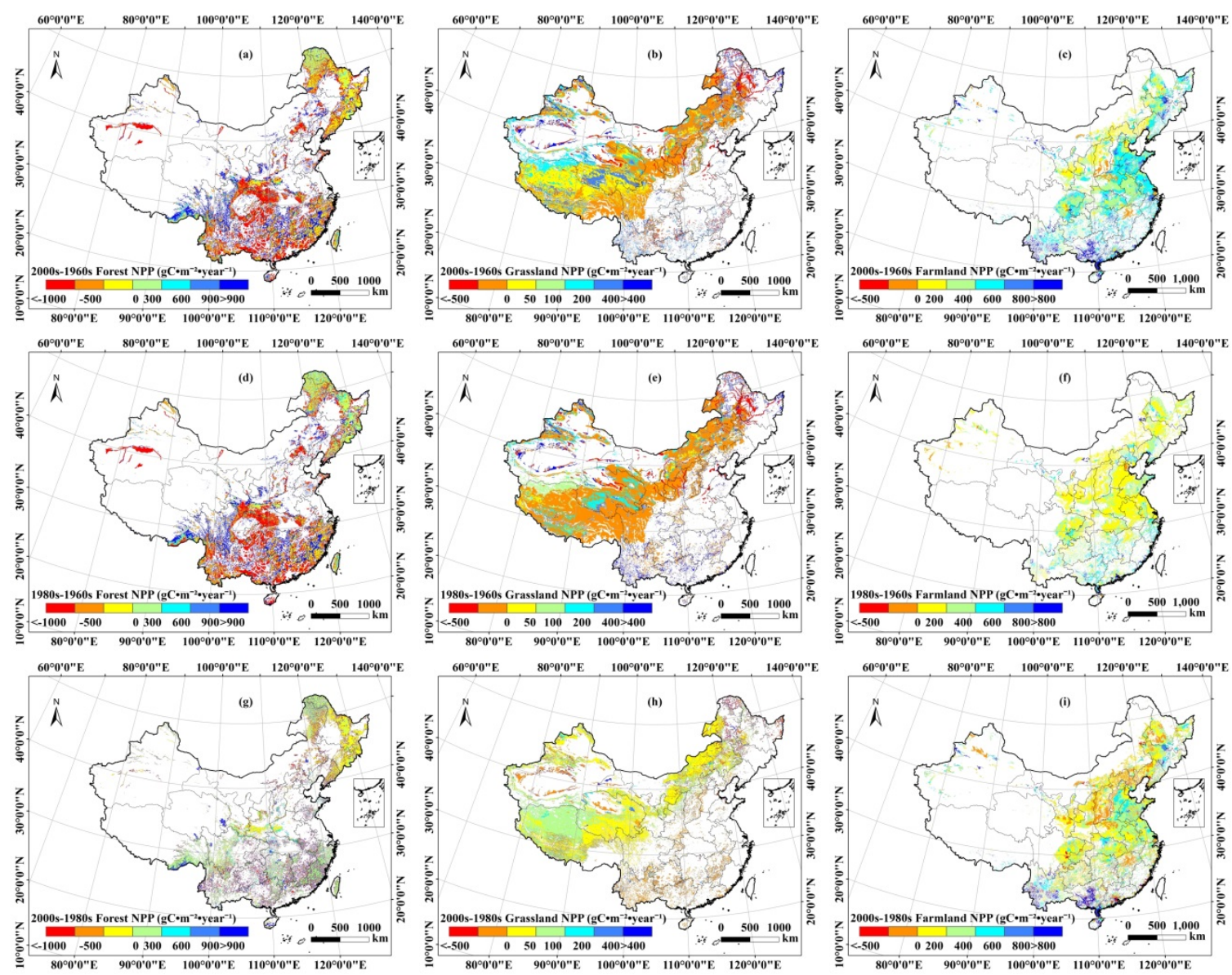

Figure 6. NPP Changes of forest, grassland and farmland from the 1960s to 2000s: (a) variation in the forest NPP from the 1960s to the 2000s; (b) variation in the grassland NPP from the 1960s to the 2000s; (c) variation in the farmland NPP from the 1960s to the 2000s; (d) variation in the forest NPP from the 1960s to the 1980s; (e) variation in the grassland NPP from the 1960s to the 1980s; (f) variation in the farmland NPP from the 1960s to the 1980s; (g) variation in the forest NPP from the 1980s to the 2000s; (h) variation in the grassland NPP from the 1980s to the 2000s; and (i) variation in the farmland NPP from the 1980s to the 2000s.

\section{Discussion}

\subsection{Uncertainties and Limitations in Estimating NPP}

In our study, based on 7618 field data obtained in the 1960s, 1980s, and 2000s, we estimated the spatial distribution and variation of NPP by vegetation classification methods, and then analyzed the relationship between NPP and climate factors. However, our results still retain some uncertainties (Table 2) for the following reasons. First, there exists a limit in the field dataset (e.g., the number of samples, and their field measurement methods). Especially from the 1960s, the field-data derived from published literature were relatively fewer, which may have resulted in some uncertainties in the estimation of NPP during the 1960s. Furthermore, there has been a rapid development of observation protocols and instruments for measurement of Vegetation NPP from the 1960s to 2000s, which may have also resulted in certain uncertainties in the datasets. Secondly, most NPP determinations as a result of the estimation methods from the published field biomass data, may have some errors, resulting in some errors for the results, but this uncertainty is likely lower compared with estimations resulting from the use of remote sensing data simulation or spatial interpolation. Thirdly, the upscaling approach may lead to biased results, especially for some samples located close to infrastructure (settlements, roads, research stations), possibly missing unmanaged areas. 
Table 2. Estimation of average NPP and total NPP from the 1960s to the 2000s.

\begin{tabular}{|c|c|c|c|c|c|c|}
\hline \multirow{2}{*}{ Vegetation Type } & \multicolumn{3}{|c|}{ Mean NPP \pm SE $\left(\mathrm{gC} \cdot \mathrm{m}^{-2} \cdot\right.$ year $\left.^{-1}\right)$} & \multicolumn{3}{|c|}{ Total NPP \pm SE $\left(\right.$ Pg C $\cdot$ year $\left.^{-1}\right)$} \\
\hline & 1960s & 1980s & $2000 s$ & 1960s & 1980s & $2000 \mathrm{~s}$ \\
\hline Forest & $1241 \pm 115$ & $1129 \pm 89$ & $1152 \pm 71$ & $2.42 \pm 0.9$ & $1.71 \pm 0.43$ & $1.96 \pm 0.41$ \\
\hline Grassland & $310 \pm 91$ & $284 \pm 81$ & $294 \pm 73$ & $0.99 \pm 0.28$ & $0.77 \pm 0.18$ & $0.83 \pm 0.2$ \\
\hline Farmland & $168 \pm 27$ & $298 \pm 21$ & $518 \pm 41$ & $0.17 \pm 0.01$ & $0.34 \pm 0.02$ & $0.62 \pm 0.05$ \\
\hline Vegetation & $584 \pm 80$ & $525 \pm 67.21$ & $596 \pm 8$ & $3.58 \pm 0.24$ & $2.82 \pm 0.14$ & $3.41 \pm 0.13$ \\
\hline
\end{tabular}

Identifying and understanding the sources of uncertainties and improving them are important in improving the accuracy of NPP. In the future, we will likely revise and circumvent potential confounds by using grid-based inventory data for reducing the uncertainties from different sources during the process of NPP estimation.

\subsection{Comparison with Other Process-Based Simulation Models and Remote Sensing Models}

Although global terrestrial NPP has increased in the northern middle and high latitudes in the past twenty years, as evidenced by numerous studies, including remote sensing data [86,87], carbon process models $[88,89]$, and numerous field measurements of plant biomass and NPP for various ecosystems in China, few detailed studies with field measurements exist on the temporal and spatial patterns of NPP trends at the country-level in China.

The major characteristics of the NPP distribution across China in this study were similar to the modeling NPP [90], which showed that high NPP values occurred in southern forested areas and low NPP in Northwest China under cold climatic conditions with low precipitation and/or low solar radiation. The total NPP of China's three periods of vegetation NPP $\left(3.58,2.82\right.$, and $\left.3.41 \mathrm{Pg} \mathrm{C} \cdot \mathrm{year}^{-1}\right)$ was also in the range of $1.43 \mathrm{Pg} \mathrm{C} \cdot$ year $^{-1}-4.60 \mathrm{Pg} \mathrm{C}$ year $^{-1}$ during $1980-2000$, as estimated by 36 process-based models and remote sensing models [91]. Specifically, the total NPP (2.82 Pg C.year $\left.{ }^{-1}\right)$ in the 1980 s was between 1.43 and $3.30 \mathrm{Pg} \mathrm{C} \cdot$ year $^{-1}$. Of the relevant research results, $77.8 \%$ lie within

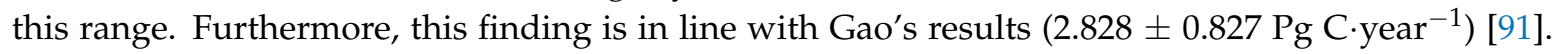
However, average NPP in this study is higher than those in other models which did not contain the higher NPP estimated by the IBIS model, which was not mentioned in its study. This could be caused by upscaling when using land cover maps.

In the dynamic characteristics of NPP, although there are differences between the study estimates performed by different researchers, the trend of the increase found in this study from 1980-2010 (Figure 7) is consistent with the increased trends of NPP in the world from 1982 to 1999 evidenced by the MOD17 NPP model [92]. The increased NPP for northern mid-latitudes $\left(22.5^{\circ} \mathrm{N}\right.$ to $\left.47.5^{\circ} \mathrm{N}\right)$ from 2000 to 2009 [15], is different from the Yuan's simulated NPP with climate change based on the IBIS, which varied from $3.61 \mathrm{Pg} \mathrm{C}$ year $^{-1}$ to $4.24 \mathrm{Pg} \mathrm{C}^{\text {year }}{ }^{-1}$ from 1961 to 2005 when warming was particularly striking [93].

The spatial distribution of terrestrial ecosystems made the simulation of NPP of China different owing to differences in approaches and uncertainties contained in the data sources $[13,94]$. Differences in this study with other process-based models and remote sensing models can result in large differences in the estimation of NPP. 


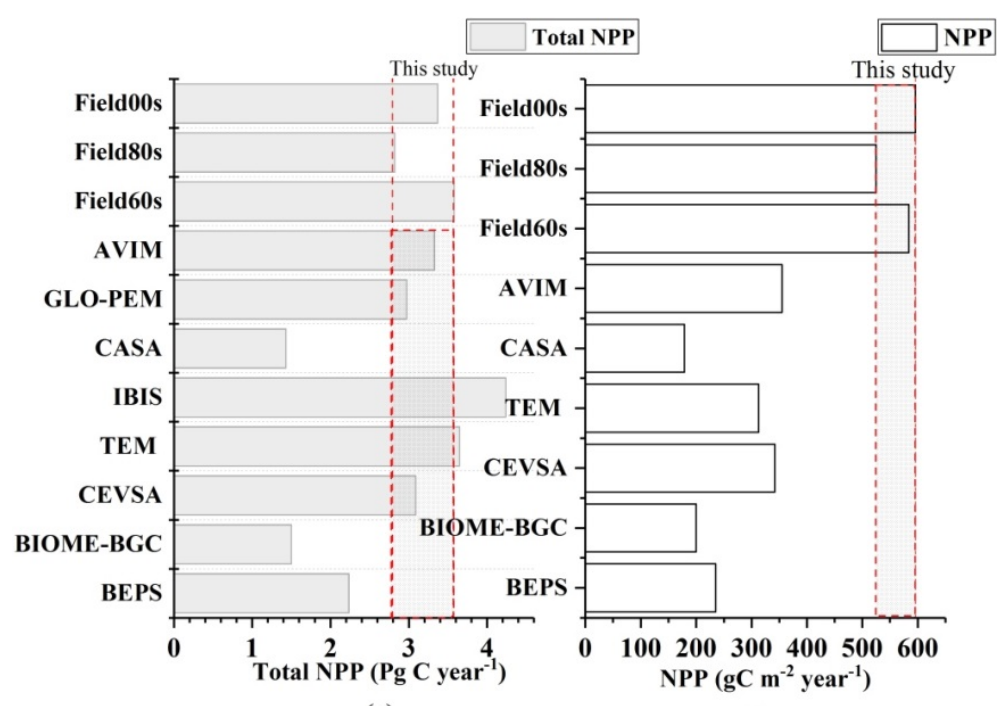

(a)

(b)

Figure 7. Research results of China's vegetation total and average NPP from the 1960s to the 2000s: (a) total NPP; and (b) average NPP.

\subsubsection{Comparison with Results Obtained by Process-Based Simulation Models}

Although numerous studies have demonstrated the usefulness of integrating a process-based ecosystem model [95] which incorporates key ecosystem processes, such as plant photosynthesis, plant respiration, decomposition of soil organic matter, and nutrient cycling with Chinese geo-referenced spatial data for examining the spatial patterns and dynamics of NPP of terrestrial ecosystems, simultaneous interactions in the processes are complex and spatially variable because of a number of controlled abiotic factors (e.g., water, light, temperature, soil texture, and nutrients). These variables ultimately lead to the simulated NPP to be underestimated (e.g., BEPS, BIOME-BGC model), or overestimated (e.g., the CEVSA model, the TEM model, and the IBIS model) compared with field measurements.

The BEPS model underestimated the NPP $\left(2.235 \mathrm{Pg} \mathrm{C} \cdot \mathrm{year}^{-1}\right)$ as it had three major limitations within the NPP results, including the quality of input data at a $1 \mathrm{~km}$ resolution, inadequate estimation for C4 plants (e.g., some grasses and crops), and underestimation of management effects on plant growth (e.g., irrigation, insect control, and fertilizer application) [90]. Similar to the BEPS model, the BIOME-BGC model also underestimated the NPP $\left(1.5-1.65 \mathrm{Pg} \mathrm{C}^{\left.-y_{e a r}{ }^{-1}\right)}\right.$ because the vegetation system was divided into only seven types, including deciduous broad-leaved forest, evergreen broad-leaved forest, evergreen coniferous forest, shrub, deciduous coniferous forest, and C3 and C4 plants. However, other eco-physiological parameters only modified the existing ecosystem type parameters [96]. Additionally, some studies have shown that percent errors of total NPP estimates from the Biome-BGC model varied from $35.2 \%$ to $43.3 \%$, and especially for belowground NPP (BNPP), the range of percent errors was 58.9-77.3\% [97].

The NPP derived from the CEVSA model was significantly overestimated in most areas of China and had a large systematic error. This model relies on climate input data, with underestimation in some mountainous areas [27]. The simulated NPP proposed by Gu et al. ranged from 3.53 to $3.96 \mathrm{Pg} \mathrm{C} \cdot$ year $^{-1}$, which is $6 \%$ to $12 \%$ higher than the reference value over the entire landmass of China, as the input climate datasets overestimated the 25 -year mean annual temperature by $7.66-12.25 \%$ and the precipitation by $2.83-8.43 \%$, respectively [27].

The TEM model, which has been used to examine patterns of NPP in South America [98], North

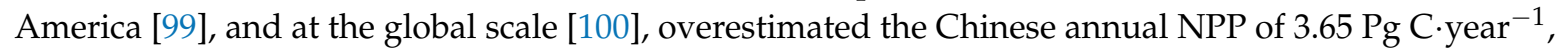
and confirmed that the temperate broadleaf evergreen forest is the most productive biome and accounts for the largest portion of annual NPP in China [95], which was similar to this study. However, the 
spatial pattern of NPP was also closely correlated to the spatial distributions of precipitation and temperature [95]. Additionally, the main limitation for simulation of TEM is the vegetation-specific parameters, which are mostly defined from published references, but only for the 18 vegetation types of the global vegetation classification [98-100]. This limitation accounts for the difference between field observation-derived NPP and simulated NPP.

Our study showed results similar to the derived from the IBIS model. Total NPP from China's

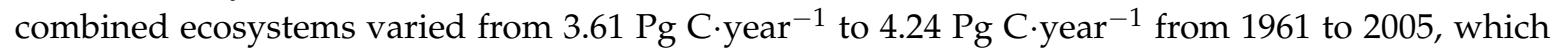
was higher than that seen in this study for the same time period. These results, in addition to the previously-mentioned limitations in existing observations, likely stem from the simulation merely approximating the NPP dynamics of a natural ecosystem while ignoring the very large influence of human activities [93].

\subsubsection{Comparison with Results Derived by Remote Sensing Estimations}

Remote sensing models (e.g., CASA, EC-LUE, GLO-PEM, MOD17) have shown the uncertainty in estimating NPP in major ecosystem types [22,101-104] where the lowest global NPP (39.9 Pg C.year $\left.{ }^{-1}\right)$ was almost $50 \%$ smaller than the maximum estimate $\left(80.5 \mathrm{Pg} \mathrm{C}_{\text {year }}{ }^{-1}\right)[81,103,104]$. Except for the MOD17 model, these remote sensing models have comparable consistency and correctly estimate spatiotemporal NPP [22]. In addition, Nemani et al. [11] reported that NPP increased globally by $6.17 \%$ (3.4 Pg C. year $^{-1}$ ) over the past 18 years, while this value was $10 \%$ during the $1980 \mathrm{~s}$, based on work by Malmström et al. [105], and Ichii et al. [106].

Our results also suggested that field NPP in China was higher [13,88,107]. For example, Piao [13] underestimated the Chinese annual NPP by $1.43 \mathrm{Pg} \mathrm{C} \cdot$ year $^{-1}$, corresponding to a total increase of $18.5 \%$ from 1982 to 1999 , using a satellite-derived NDVI, CASA model [13], which was 20.79\% lower than the estimate in this study. Such NPP results calculated from CASA can also be evidenced from nationwide forest inventory surveys [108] and the well-documented food yield statistics [88]. The underestimated NPP by the NDVI product is due to satellite drift or change over time, and incomplete corrections for calibration loss and atmospheric effects (clouds, aerosols, etc.). At the same time, in the case of dense leaf canopies in humid tropical forests and old growth forests [109,110], NPP also may be underestimated.

\subsubsection{Comparison with Vegetation Types}

Except for the differences in approaches and data sources, the distribution of vegetation types was also the main reason for errors in NPP estimation. The mapped area of different vegetation types is, itself, an estimate, that may contain inherent error, affecting the estimation of total and mean NPP.

In this study, the areas obtained from the spatial distribution of vegetation types in China (the 1960s, 1980s, and 2000s) were different from other studies and secondary surveys. The farmland area $\left(119.31 \times 10^{4} \mathrm{~km}^{2}\right)$ used in this study was slightly smaller than that of the farmland area $\left(135.39 \times 110^{4} \mathrm{~km}^{2}\right)$ cited in the Second National Land Survey. For grassland, the area $\left(281.98 \times 10^{4} \mathrm{~km}^{2}\right)$ in the 2000s was essentially the same as that of the grassland area $\left(287.31 \times 110^{4} \mathrm{~km}^{2}\right)$ in the Second National Land Survey, but smaller than that estimated by Fang $\left(331 \times 10^{4} \mathrm{~km}^{2}\right)$ [111]. In addition, the field total grassland NPP $\left(0.73 \mathrm{Pg} \mathrm{C} \cdot\right.$ year $\left.^{-1}\right)$ in the $1980 \mathrm{~s}$ was significantly lower than that $\left(1.04 \mathrm{Pg} \mathrm{C} \cdot\right.$ year $\left.^{-1}\right)$ estimated by Piao (2004) based on the NDVI model [70], as the latter area is larger $\left(331.41 \times 10^{4} \mathrm{~km}^{2}\right)$ than the former $\left(271.76 \times 10^{4} \mathrm{~km}^{2}\right)$.

The forest area $\left(170.14 \times 10^{4} \mathrm{~km}^{2}\right)$ in the 2000 s was slightly larger than that estimated by Fang $\left(142.8 \times 10^{4} \mathrm{~km}^{2}\right)$, which is far lower than that of the second-order forest area $\left(253.95 \times 10^{4} \mathrm{~km}^{2}\right)$. However, the increasing trend in the area from the 1980s to the 2000s was consistent with the results cited by Fang. At the same time, Forest NPP $\left(1129 \mathrm{gC} \cdot \mathrm{m}^{-2} \cdot \mathrm{year}^{-1}\right)$ was close to that calculated by Luo $\left(1205 \mathrm{gC} \cdot \mathrm{m}^{-2} \cdot\right.$ year $\left.^{-1}\right)$, which is higher than that $\left(984 \mathrm{gC} \cdot \mathrm{m}^{-2} \cdot\right.$ year $\left.^{-1}\right)$ estimated based on the average volume of forest in China by Fang from 1982 to 1989 [88], but with smaller areas $\left(116.5 \times 10^{4} \mathrm{~km}^{2}\right)$ 
than that of this study $\left(151.38 \times 10^{4} \mathrm{~km}^{2}\right)$, Thus, the NPP $\left(1.00 \mathrm{Pg} \mathrm{C} \cdot \mathrm{year}^{-1}\right)$ calculated according to the third forest resource inventory data was lower than that of our study (1.71 Pg C.year $\left.{ }^{-1}\right)$.

\subsection{Impact of Climate Change on NPP}

Many studies have suggested that climate change is probably a major controller in the overall response of NPP $[13,94,95,112,113]$. Based on the complex processes (Figure S2), and the significant climate changes in China [114,115], these factors may have resulted in large variations in China's terrestrial ecosystem production. The distribution of NPP and historical trends in this study indicated a high degree of spatial heterogeneity and large regional variations, coupled with regional climate variations, including temperature, precipitation, and solar radiation. The effect of temperature on NPP changes was stronger than that of precipitation, such as in the Hengduan Mountains area of China [112], while other areas may show opposite effects. The effect of climate variations also had regional differences.

Taking grassland NPP as an example (Table 3), there was a significant positive correlation between NPP, precipitation, and solar radiation, and a significant negative correlation with temperature. The effects of precipitation and solar radiation on grassland NPP were greater than that of temperature.

In terms of the specific types of grassland, the average coefficient of the partial correlation of precipitation to desert steppe, typical steppe, and meadow steppe was higher than that of meadow type (typical meadow, swamp meadow, and salinized meadow). However, the NPP of alpine meadow was significantly negatively correlated with precipitation, and positively correlated with temperature, whose influence is greater than precipitation. Temperature and desert grassland, temperate grasslands, subtropical and tropical grasslands, marsh meadow, and salinized meadow have significant negative correlations, which is largest for Grasslands. In addition, there is a significant positive correlation among meadow grassland, typical grassland, typical meadow, and alpine meadow. The average coefficient of partial correlation of solar radiation to meadow steppe (grass, Carex and forb swamp meadows, grass and forb halophytic meadows), temperate tufted low grass, nano-semi-shrub desert steppes, and temperate grasslands was higher. At the same time, the solar radiation and grass, Carex spp. high-cold steppes had a small negative correlation.

Furthermore, the trends of NPP was in line with the trend of climate factors. The average annual temperatures increased significantly in most areas, and precipitation also increased in South and Northeastern China, whereas the north and northwest regions were relatively reduced. This is in line with the decreasing trend of the southern vegetation (mainly forested) NPP and the trend of growth of northern vegetation (mainly grassland) NPP. In Southern China, the temperature is the main factor affecting NPP [11], and water is not closely related to temperature. In Northern China, precipitation was the main factor affecting vegetation NPP [116], but vegetation NPP is also affected by human irrigation in some areas, and precipitation may be less than the effect of temperature, such as the eastern part of North China and in Northeast China [11]. There was also a significant positive correlation between the time variation of vegetation NPP and the average annual solar radiation. Both were decreased significantly overall, but rose slightly in the later period in most areas. In all, the trends of NPP may be the result of the combined effects of temperature, precipitation, solar radiation, and human irrigation, rather than a single factor.

Table 3. The partial correlation coefficients between grassland NPP and climate factors.

\begin{tabular}{cccccccccccc}
\hline Climatic Factors & $\mathbf{3 1}$ & $\mathbf{3 2}$ & $\mathbf{3 3}$ & $\mathbf{3 4}$ & $\mathbf{3 5}$ & $\mathbf{3 6}$ & $\mathbf{3 7}$ & $\mathbf{3 8}$ & $\mathbf{3 9}$ & $\mathbf{4 0}$ \\
\hline Precipitation & 0.41 & 0.62 & 0.65 & 0.62 & 0.44 & -0.15 & 0.49 & 0.51 & 0.32 & -0.31 \\
Temperature & 0.62 & 0.38 & -0.35 & 0.26 & -0.81 & -0.73 & 0.26 & -0.54 & -0.87 & 0.71 \\
Solar radiation & 0.42 & 0.51 & 0.93 & -0.20 & 0.90 & 0.74 & 0.22 & 0.93 & 1.00 & 0.35 \\
\hline
\end{tabular}

Note: The meaning of the id number for grassland (31-40) can be seen in Table S1. 


\section{Conclusions}

In this study, Chinese vegetation, including forest, grassland, and farmland NPP, were firstly estimated with field data for long-term time series. Then, the temporal and spatial variation and drivers in vegetation NPP and individual vegetation NPP from the 1960 s to the 2000 s were analyzed. The values of other relevant NPP models, as well as process-based simulation and remote sensing models, were compared. Lastly, the uncertainties of field NPP of this study were discussed. Our research provides valuable information and a basis for validation analyses by remote sensing models, as well as a robust quantification of carbon estimation to anticipate future development at the national and global scale.

Generally, Chinese vegetation NPP ranged from 3 to $12,407 \mathrm{gC} \cdot \mathrm{m}^{-2} \cdot$ year $^{-1}$ with a mean value of $571 \mathrm{gC} \cdot \mathrm{m}^{-2} \cdot$ year $^{-1}$. Forest, farmland, and grassland NPP were 1152,518 , and $294 \mathrm{gC} \cdot \mathrm{m}^{-2} \cdot$ year $^{-1}$, respectively. However, total NPP in grassland was higher than farmland.

The distribution of vegetation NPP in China had large spatial heterogeneity and large regional variations. It gradually decreases from the southeast to the northwest. The relatively higher value is mainly in tropical forest types and swamp meadows, with a mean value of $2642 \mathrm{gC} \cdot \mathrm{m}^{-2} \cdot \mathrm{year}^{-1}$ and $^{-}$ $455 \mathrm{gC} \cdot \mathrm{m}^{-2} \cdot$ year $^{-1}$, respectively, which is distributed primarily in the southern Chinese provinces of Hainan, Fujian, Guangxi, and the southeast margin of Tibet province. The lower NPP is mainly in desert grassland types, with a mean NPP of $214 \mathrm{gC} \cdot \mathrm{m}^{-2} \cdot \mathrm{year}^{-1}$, which distributed in the Hexi Corridor, the extremely arid desert areas in the northwest part of the Alashan area, and the Mazongshan-Nuo Min Gobi shrubs.

The total vegetation NPP fell from 3.58 to $3.41 \mathrm{Pg} \mathrm{C}$.year ${ }^{-1}$ from the 1960 s to $2000 \mathrm{~s}$, with a decrease of $4.7 \%$. The trends in forest and grassland were similar, with a decrease of $0.46 \mathrm{Pg} \mathrm{C} \cdot \mathrm{year}^{-1}$ and $^{-}$ $0.16 \mathrm{Pg} \mathrm{C} \cdot$ year $^{-1}$, nearly $-4.5 \%$ and $-0.8 \%$ per year, respectively, whereas farmland NPP was in the opposite direction, with the growth of $0.45 \mathrm{Pg} \mathrm{C} \cdot$ year $^{-1}$ and $18 \mathrm{gC} \cdot \mathrm{m}^{-2} \cdot$ year $^{-1}$. Chinese vegetation NPP decreased in the 1960s-1980s and increased the 1980s-2000s, but the reduction of the former period $\left(-0.76 \mathrm{Pg} \mathrm{C} \cdot\right.$ year $\left.^{-1}\right)$ was higher than the increase in the latter period $\left(0.59 \mathrm{Pg} \mathrm{C} \cdot\right.$ year $\left.^{-1}\right)$. In addition, forest and grassland NPP showed similar trends, but farmland NPP showed an increasing trend.

Precipitation, temperature, and solar radiation were the dominant factors affecting the spatial variability of NPP in the north and south of China, respectively. In addition, the effect of precipitation on grassland NPP was higher than temperature and solar radiation, especially for deserts, followed by steppes and meadows.

Supplementary Materials: The following are available online at http:/ /www.mdpi.com/2072-4292/10/6/860/s1, Figure S1. Distribution of Chinese vegetation from the 1960 s to 2000 s, Figure S2. The influence of climate change to NPP, Table S1. Chinese vegetation classification, Table S2, Table S3, and Table S4. The summarized coefficients for estimation of farmland NPP, grassland NPP, and forest NPP, Table S5. The abbreviations of Chinese provinces, Abbreviations.

Author Contributions: E.S., H.Z., and F.L. conceived and designed the experiments; E.S. and F.L. performed the model; E.S., E.X., and F.L. analyzed the data; E.S. wrote the paper; and H.Z. and E.X. reviewed the manuscript.

Funding: This research was funded by the Strategic Priority Research Program of the Chinese Academy of Sciences grant number [XDA19040305], the National Natural Science Foundation of China [41601095], and the Strategic Priority Research Program of the Chinese Academy of Sciences [XDA05090305].

Acknowledgments: This work was supported by the Strategic Priority Research Program of the Chinese Academy of Sciences (XDA19040305), the National Natural Science Foundation of China (41601095), and the Strategic Priority Research Program of the Chinese Academy of Sciences (XDA05090305). We appreciate the constructive comments from the three anonymous reviewers. We also thank Editage for English editing.

Conflicts of Interest: The authors declare no conflict of interest.

\section{References}

1. Cramer, W.; Field, C.B. Comparing global models of terrestrial net primary productivity (NPP): Introduction. Glob. Chang. Biol. 1999, 5, 3-4. [CrossRef] 
2. Field, C.B.; Behrenfeld, M.J.; Randerson, J.T.; Falkowski, P.G. Primary production of the biosphere: Integrating terrestrial and oceanic components. Science 1998, 281, 237-240. [CrossRef] [PubMed]

3. Guan, X.B.; Shen, H.F.; Gan, W.X.; Yang, G.; Wang, L.C.; Li, X.H.; Zhang, L.P. A 33-year NPP monitoring study in southwest China by the fusion of multi-source remote sensing and station data. Remote Sens. 2017, 9, 1082. [CrossRef]

4. Haberl, H.; Erb, K.H.; Krausmann, F.; Gaube, V.; Bondeau, A.; Plutzar, C.; Gingrich, S.; Lucht, W.; Fischer-Kowalski, M. Quantifying and mapping the human appropriation of net primary production in earth's terrestrial ecosystems. Proc. Natl. Acad. Sci. USA 2007, 104, 12942-12947. [CrossRef] [PubMed]

5. Steffen, W.; Noble, I.; Canadell, J.; Apps, M.; Schulze, E.D.; Jarvis, P.G.; Baldocchi, D.; Ciais, P.; Cramer, W.; Ehleringer, J.; et al. The terrestrial carbon cycle: Implications for the kyoto protocol. Science 1998, 280, 1393-1394.

6. Imhoff, M.L.; Bounoua, L.; DeFries, R.; Lawrence, W.T.; Stutzer, D.; Tucker, C.J.; Ricketts, T. The consequences of urban land transformation on net primary productivity in the United States. Remote Sens. Environ. 2004, 89, 434-443. [CrossRef]

7. Chen, C.B.; Zhang, C. Projecting the $\mathrm{CO}_{2}$ and climatic change effects on the net primary productivity of the urban ecosystems in phoenix, $\mathrm{AZ}$ in the 21st century under multiple RCP (representative concentration pathway) scenarios. Sustainability 2017, 9, 1366. [CrossRef]

8. Potter, C.; Klooster, S.; Myneni, R.; Genovese, V.; Tan, P.N.; Kumar, V. Continental-scale comparisons of terrestrial carbon sinks estimated from satellite data and ecosystem modeling 1982-1998. Glob. Planet. Chang. 2003, 39, 201-213. [CrossRef]

9. Zhu, Q.; Zhao, J.J.; Zhu, Z.H.; Zhang, H.Y.; Zhang, Z.X.; Guo, X.Y.; Bi, Y.Z.; Sun, L. Remotely sensed estimation of net primary productivity (NPP) and its spatial and temporal variations in the greater khingan mountain region, China. Sustainability 2017, 9, 1213. [CrossRef]

10. Zhao, F.; Xu, B.; Yang, X.C.; Jin, Y.X.; Li, J.Y.; Xia, L.; Chen, S.; Ma, H.L. Remote sensing estimates of grassland aboveground biomass based on MODIS net primary productivity (NPP): A case study in the xilingol grassland of northern China. Remote Sens. 2014, 6, 5368-5386. [CrossRef]

11. Nemani, R.R.; Keeling, C.D.; Hashimoto, H.; Jolly, W.M.; Piper, S.C.; Tucker, C.J.; Myneni, R.B.; Running, S.W. Climate-driven increases in global terrestrial net primary production from 1982 to 1999. Science 2003, 300, 1560-1563. [CrossRef] [PubMed]

12. Ciais, P.; Reichstein, M.; Viovy, N.; Granier, A.; Ogee, J.; Allard, V.; Aubinet, M.; Buchmann, N.; Bernhofer, C.; Carrara, A.; et al. Europe-wide reduction in primary productivity caused by the heat and drought in 2003. Nature 2005, 437, 529-533. [CrossRef] [PubMed]

13. Piao, S.L.; Fang, J.Y.; Zhou, L.M.; Zhu, B.; Tan, K.; Tao, S. Changes in vegetation net primary productivity from 1982 to 1999 in China. Glob. Biogeochem. Cycle 2005, 19. [CrossRef]

14. Piao, S.L.; Fang, J.Y.; Ciais, P.; Peylin, P.; Huang, Y.; Sitch, S.; Wang, T. The carbon balance of terrestrial ecosystems in China. Nature 2009, 458, U1009-U1082. [CrossRef] [PubMed]

15. Zhao, M.S.; Running, S.W. Drought-induced reduction in global terrestrial net primary production from 2000 through 2009. Science 2010, 329, 940-943. [CrossRef] [PubMed]

16. Potter, C.; Klooster, S.; Genovese, V. Net primary production of terrestrial ecosystems from 20002009. Clim. Chang. 2012, 115, 365-378. [CrossRef]

17. Pei, F.S.; Li, X.; Liu, X.P.; Wang, S.J.; He, Z.J. Assessing the differences in net primary productivity between pre- and post-urban land development in China. Agric. For. Meteorol. 2013, 171, 174-186. [CrossRef]

18. Rafique, R.; Zhao, F.; de Jong, R.; Zeng, N.; Asrar, G.R. Global and regional variability and change in terrestrial ecosystems net primary production and NDVI: A model-data comparison. Remote Sens. 2016, 8, 177. [CrossRef]

19. Yuan, J.G.; Niu, Z.; Wang, C.L. Vegetation NPP distribution based on MODIS data and CASA model-A case study of northern Hebei province. Chin. Geogr. Sci. 2006, 16, 334-341. [CrossRef]

20. Zhang, Y.; Zhang, X.L. Estimation of net primary productivity of different forest types based on improved CASA model in Jing-Jin-Ji region, China. J. Sustain. For. 2017, 36, 568-582. [CrossRef]

21. Liu, W.; Feng, Q.; Zhang, F.P. Spatial-temporal variation characteristics of NPP in the Heihe River Basin, northwestern China, in a recent 10-year period calculated by casa model. J. Coast. Res. 2017, 80, 36-47. [CrossRef] 
22. Sannigrahi, S. Modeling terrestrial ecosystem productivity of an estuarine ecosystem in the Sundarban Biosphere Region, India using seven ecosystem models. Ecol. Model. 2017, 356, 73-90. [CrossRef]

23. Tian, G.J.; Qiao, Z. Assessing the impact of the urbanization process on net primary productivity in China in 1989-2000. Environ. Pollut. 2014, 184, 320-326. [CrossRef] [PubMed]

24. Yuan, W.P.; Liu, S.; Zhou, G.S.; Zhou, G.Y.; Tieszen, L.L.; Baldocchi, D.; Bernhofer, C.; Gholz, H.; Goldstein, A.H.; Goulden, M.L.; et al. Deriving a light use efficiency model from eddy covariance flux data for predicting daily gross primary production across biomes. Agric. For. Meteorol. 2007, 143, $189-207$. [CrossRef]

25. Sun, X.Y.; Wang, G.X.; Huang, M.; Hu, Z.Y.; Song, C.L. Effect of climate change on seasonal water use efficiency in subalpine Abies fabri. J. Mt. Sci. 2017, 14, 142-157. [CrossRef]

26. Wu, S.H.; Yin, Y.H.; Zhao, D.S.; Huang, M.; Shao, X.M.; Dai, E.F. Impact of future climate change on terrestrial ecosystems in China. Int. J. Climatol. 2010, 30, 866-873. [CrossRef]

27. Gu, F.X.; Zhang, Y.D.; Huang, M.; Tao, B.; Liu, Z.J.; Hao, M.; Guo, R. Climate-driven uncertainties in modeling terrestrial ecosystem net primary productivity in China. Agric. For. Meteorol. 2017, 246, 123-132. [CrossRef]

28. Wang, C.D.; Zhang, S.Y.; Yan, W.L.; Wang, R.Q.; Liu, J.; Wang, Y.T. Evaluating renewable natural resources flow and net primary productivity with a gis-emergy approach: A case study of Hokkaido, Japan. Sci. Rep. 2016, 6. [CrossRef] [PubMed]

29. Sellers, P.J.; Meeson, B.W.; Hall, F.G.; Asrar, G.; Murphy, R.E.; Schiffer, R.A.; Bretherton, F.P.; Dickinson, R.E.; Ellingson, R.G.; Field, C.B.; et al. Remote-sensing of the land-surface for studies of global change-Models, algorithms, experiments. Remote Sens. Environ. 1995, 51, 3-26. [CrossRef]

30. Patenaude, G.; Hill, R.A.; Milne, R.; Gaveau, D.L.A.; Briggs, B.B.J.; Dawson, T.P. Quantifying forest above ground carbon content using lidar remote sensing. Remote Sens. Environ. 2004, 93, 368-380. [CrossRef]

31. Mitchell, S.W.; Csillag, F. Assessing the stability and uncertainty of predicted vegetation growth under climatic variability: Northern mixed grass prairie. Ecol. Model. 2001, 139, 101-121. [CrossRef]

32. Hemming, D.; Betts, R.; Collins, M. Sensitivity and uncertainty of modelled terrestrial net primary productivity to doubled $\mathrm{CO}_{2}$ and associated climate change for a relatively large perturbed physics ensemble. Agric. For. Meteorol. 2013, 170, 79-88. [CrossRef]

33. Kicklighter, D.W.; Bondeau, A.; Schloss, A.L.; Kaduk, J.; McGuire, A.D.; Intercomparison, P.P.N.M. Comparing global models of terrestrial net primary productivity (NPP): Global pattern and differentiation by major biomes. Glob. Chang. Biol. 1999, 5, 16-24. [CrossRef]

34. Lauenroth, W.K.; Wade, A.A.; Williamson, M.A.; Ross, B.E.; Kumar, S.; Cariveau, D.P. Uncertainty in calculations of net primary production for grasslands. Ecosystems 2006, 9, 843-851. [CrossRef]

35. Chen, L.J.; Liu, G.H.; Feng, X.F. Estimation of net primary productivity of terrestrial vegetation in China by remote sensing. Acta Bot. Sin. 2001, 43, 1191-1198.

36. Tao, F.L.; Yokozawa, M.; Zhang, Z.; Xu, Y.L.; Hayashi, Y. Remote sensing of crop production in China by production efficiency models: Models comparisons, estimates and uncertainties. Ecol. Model. 2005, 183, 385-396. [CrossRef]

37. Ni, J. Net primary productivity in forests of China: Scaling-up of national inventory data and comparison with model predictions. For. Ecol. Manag. 2003, 176, 485-495. [CrossRef]

38. Reich, P.B.; Turner, D.P.; Bolstad, P. An approach to spatially distributed modeling of net primary production (NPP) at the landscape scale and its application in validation of EOS NPP products. Remote Sens. Environ. 1999, 70, 69-81. [CrossRef]

39. Ichii, K.; Kondo, M.; Okabe, Y.; Ueyama, M.; Kobayashi, H.; Lee, S.J.; Saigusa, N.; Zhu, Z.C.; Myneni, R.B. Recent changes in terrestrial gross primary productivity in Asia from 1982 to 2011. Remote Sens. 2013, 5, 6043-6062. [CrossRef]

40. Zhu, L.K.; Southworth, J. Disentangling the relationships between net primary production and precipitation in Southern Africa savannas using satellite observations from 1982 to 2010. Remote Sens. 2013, 5, 3803-3825. [CrossRef]

41. Guo, Q.; Fu, B.H.; Shi, P.L.; Cudahy, T.; Zhang, J.; Xu, H. Satellite monitoring the spatial-temporal dynamics of desertification in response to climate change and human activities across the ordos plateau, China. Remote Sens. 2017, 9, 525. [CrossRef] 
42. Zhang, R.; Zhou, Y.; Luo, H.X.; Wang, F.T.; Wang, S.X. Estimation and analysis of spatiotemporal dynamics of the net primary productivity integrating efficiency model with process model in karst area. Remote Sens. 2017, 9, 477. [CrossRef]

43. Wu, S.H.; Zhou, S.L.; Chen, D.X.; Wei, Z.Q.; Dai, L.; Li, X.G. Determining the contributions of urbanisation and climate change to NPP variations over the last decade in the Yangtze River Delta, China. Sci. Total Environ. 2014, 472, 397-406. [CrossRef] [PubMed]

44. Wang, X.G.; Zhou, M.H.; Li, T.; Ke, Y.; Zhu, B. Land use change effects on ecosystemcarbon budget in the Sichuan Basin of southwest China: Conversion of cropland to forest ecosystem. Sci. Total Environ. 2017, 609, 556-562. [CrossRef] [PubMed]

45. Zhang, F.Y.; Quan, Q.; Song, B.; Sun, J.; Chen, Y.J.; Zhou, Q.P.; Niu, S.L. Net primary productivity and its partitioning in response to precipitation gradient in an alpine meadow. Sci. Rep. 2017, 7, 15193. [CrossRef] [PubMed]

46. Shao, J.; Zhou, X.H.; Luo, Y.Q.; Zhang, G.D.; Yan, W.; Li, J.X.; Li, B.; Dan, L.; Fisher, J.B.; Gao, Z.Q.; et al. Uncertainty analysis of terrestrial net primary productivity and net biome productivity in China during 1901-2005. J. Geophys. Res. Biogeosci. 2016, 121, 1372-1393. [CrossRef]

47. Environmental and Ecological Science Data Center for West China, National Natural Science Foundation of China. Available online: http:/ / westdc.westgis.ac.cn (accessed on 31 May 2018).

48. Hou, X.Y. Vegetation Atlas of China (1:1,000,000); Science Press: Beijing, China, 2001. (In Chinese)

49. National Earth System Science Data Sharing Infrastructure, National Science \& Technology Infrastructure of China. Available online: http:/ / www.geodata.cn (accessed on 31 May 2018).

50. Cai, X.M. Ecosystem Ecology; Science Press: Beijing, China, 2000. (In Chinese)

51. Baldocchi, D.; Falge, E.; Gu, L.; Olson, R.; Hollinger, D.; Running, S.; Anthoni, P.; Bernhofer, C.; Davis, K.; Evans, R. Fluxnet: A new tool to study the temporal and spatial variability of ecosystem-scale carbon dioxide, water vapor, and energy flux densities. Bull. Am. Meteorol. Soc. 2001, 82, 2415-2434. [CrossRef]

52. Ťupek, B.; Zanchi, G.; Verkerk, P.J.; Churkina, G.; Viovy, N.; Hughes, J.K.; Lindner, M. A comparison of alternative modelling approaches to evaluate the European forest carbon fluxes. For. Ecol. Manag. 2010, 260, 241-251. [CrossRef]

53. China National Knowledge Infrastructure Database. Available online: http:/ /www.cnki.net/ (accessed on 31 May 2018).

54. Web of Science. Available online: www.webofknowledge.com (accessed on 31 May 2018).

55. China Statistical Yearbooks Database. Available online: http://tongji.cnki.net/overseas/Dig/Dig.aspx\# (accessed on 31 May 2018).

56. National Planning Commission Natural Resources Comprehensive Inspection. 40 Years of Comprehensive Study of Natural Resources; China Science and Technology Press: Beijing, China, 1996. (In Chinese)

57. Luo, T.X. China's Main Forest Type Biological Productivity Pattern and Its Mathematical Model; Graduate School of Chinese Academy of Sciences: Beijing, China, 1996. (In Chinese)

58. Global Primary Production Data Initiative (GPPDI). Available online: https://daac.ornl.gov/cgi-bin/ dataset_lister.pl?p=13 (accessed on 31 May 2018).

59. Lobell, D.B.; Hicke, J.A.; Asner, G.P.; Field, C.B.; Tucker, C.J.; Los, S.O. Satellite estimates of productivity and light use efficiency in united states agriculture, 1982-98. Glob. Chang. Biol. 2002, 8, 722-735. [CrossRef]

60. Yan, H.M.; Cao, M.K. Spatial pattern and topographic control of China's agricultural productivity variability. Acta Geogr. Sin. 2007, 62, 171-180. (In Chinese)

61. Fang, J.Y.; Liu, G.H.; Xu, S.L.; Wang, G.C.; Wen, Y.P. Carbon Storage of Terrestrial Ecosystem in China; Chinese Environment Sciences Press: Beijing, China, 1996. (In Chinese)

62. Abdi, A.M.; Vrieling, A.; Yengoh, G.T.; Anyamba, A.; Seaquist, J.W.; Ummenhofer, C.C.; Ardö, J. The el niño-La niña cycle and recent trends in supply and demand of net primary productivity in African drylands. Clim. Chang. 2016, 138, 111-125. [CrossRef]

63. Hay, R.K.M. Harvest index-A review of its use in plant-breeding and crop physiology. Ann. Appl. Biol. 1995, 126, 197-216. [CrossRef]

64. Guo, Z.X.; Wang, Z.M.; Liu, D.W.; Song, K.S.; Song, C.C.; Song, C. Analysis of temporal and spatial features of farmland productivity in the Sanjiang Plain. Trans. Chin. Soc. Agric. Eng. 2009, 25, 249-254.

65. Steingrobe, B.; Schmid, H.; Gutser, R.; Claassen, N. Root production and root mortality of winter wheat grown on sandy and loamy soils in different farming systems. Biol. Fertil. Soils 2001, 33, 331-339. [CrossRef] 
66. Hicke, J.A.; Lobell, D.B.; Asner, G.P. Cropland area and net primary production computed from 30 years of USDA agricultural harvest data. Earth Interact. 2004, 8, 1-20. [CrossRef]

67. Scurlock, J.M.O.; Johnson, K.; Olson, R.J. Estimating net primary productivity from grassland biomass dynamics measurements. Glob. Chang. Biol. 2002, 8, 736-753. [CrossRef]

68. Ni, J. Estimating net primary productivity of grasslands from field biomass measurements in temperate northern China. Plant Ecol. 2004, 174, 217-234. [CrossRef]

69. Liu, F.; Zhang, H.Q.; Xu, E.Q.; Kang, L. Responses of grassland net primary productivity to environmental variables in northern China. J. Resour. Ecol. 2016, 7, 92-100.

70. Piao, S.L.; Fang, J.Y.; He, J.S.; Xiao, Y. Spatial distribution of grassland biomass in China. Chin. J. Plant Ecol. 2004, 28, 491-498. (In Chinese)

71. Commission for Integrated Survey of Natural Resources of the Chinese Academy of Science. Data on Grassland Resources of China; China Agriculture Science and Technology Press: Beijing, China, 1994. (In Chinese)

72. Fang, J.Y.; Xu, S.L. Biomass and net production of forest vegegation in China. Acta Ecol. Sin. 1996, 16, 497-508. (In Chinese)

73. Liao, G.F. General Situation of Natural Grassland Resources in the Western and Northern Parts of China; Science Press: Beijing, China, 1964. (In Chinese)

74. Zhao, M.; Zhou, G.S. Estimation of biomass and net primary productivity of major planted forests in China based on forest inventory data. For. Ecol. Manag. 2005, 207, 295-313. [CrossRef]

75. Wang, Y.H.; Zhou, G.S.; Jiang, Y.L.; Yang, Z.Y. Estimating biomass and NPP of larix forests using forest inventory data. Acta Phytoecol. Sin. 2001, 25, 420-425. (In Chinese)

76. Wang, B.; Liu, M.C.; Zhang, B. Dynamics of net production of Chinese forest vegetation based on forest inventory data. For. Resour. Manag. 2009, 1, 35-43.

77. Fang, O.Y.; Wang, Y.; Shao, X.M. The effect of climate on the net primary productivity (NPP) of Pinus koraiensis in the Changbai Mountains over the past 50 years. Trees Struct. Funct. 2016, 30, 281-294. [CrossRef]

78. Reich, P.B.; Luo, Y.J.; Bradford, J.B.; Poorter, H.; Perry, C.H.; Oleksyn, J. Temperature drives global patterns in forest biomass distribution in leaves, stems, and roots. Proc. Natl. Acad. Sci. USA 2014, 111, 13721-13726. [CrossRef] [PubMed]

79. Fang, J.Y.; Shen, Z.H.; Tang, Z.Y.; Wang, X.P.; Wang, Z.H.; Feng, J.M.; Liu, Y.N.; Qiao, X.J.; Wu, X.P.; Zheng, C.Y. Forest community survey and the structural characteristics of forests in China. Ecography 2012, 35, 1059-1071. [CrossRef]

80. Peng, S.L.; Wen, D.; He, N.P.; Yu, G.R.; Ma, A.N.; Wang, Q.F. Carbon storage in China's forest ecosystems: Estimation by different integrative methods. Ecol. Evol. 2016, 6, 3129-3145. [CrossRef] [PubMed]

81. Cramer, W.; Kicklighter, D.W.; Bondeau, A.; Iii, B.M.; Churkina, G.; Nemry, B.; Ruimy, A.; Schloss, A.L. Comparing global models of terrestrial net primary productivity (NPP): Overview and key results. Glob. Chang. Biol. 1999, 5, 1-15. [CrossRef]

82. Huntzinger, D.N.; Schwalm, C.; Michalak, A.M.; Schaefer, K.; King, A.W.; Wei, Y.; Jacobson, A.; Liu, S.; Cook, R.B.; Post, W.M.; et al. The North American carbon program multi-scale synthesis and terrestrial model intercomparison project-Part 1: Overview and experimental design. Geosci. Model Dev. 2013, 6, 2121-2133. [CrossRef]

83. Schwalm, C.R.; Williams, C.A.; Schaefer, K.; Anderson, R.; Arain, M.A.; Baker, I.; Barr, A.; Black, T.A.; Chen, G.S.; Chen, J.M.; et al. A model-data intercomparison of $\mathrm{CO}_{2}$ exchange across North America: Results from the North American carbon program site synthesis. J. Geophys. Res. Biogeosci. 2010, 115. [CrossRef]

84. Pasw Statistics for Windows, version 18; SPSS Inc.: Chicago, IL, USA, 2009.

85. Arcgis 10.1 Available Soon. Available online: https://blogs.esri.com/esri/arcgis/2012/06/11/arcgis-10-1available-soon/ (accessed on 31 May 2018).

86. Piao, S.L.; Fang, J.Y.; Zhou, L.M.; Guo, Q.H.; Henderson, M.; Ji, W.; Li, Y.; Tao, S. Interannual variations of monthly and seasonal normalized difference vegetation index (NDVI) in China from 1982 to 1999. J. Geophys. Res. Atmos. 2003, 108. [CrossRef]

87. Slayback, D.A.; Pinzon, J.E.; Los, S.O.; Tucker, C.J. Northern hemisphere photosynthetic trends 1982-99. Glob. Chang. Biol. 2003, 9, 1-15. [CrossRef]

88. Fang, J.Y.; Piao, S.L.; Field, C.B.; Pan, Y.D.; Guo, Q.H.; Zhou, L.M.; Peng, C.H.; Tao, S. Increasing net primary production in china from 1982 to 1999. Front. Ecol. Environ. 2003, 1, 293-297. [CrossRef] 
89. Hicke, J.A.; Asner, G.P.; Randerson, J.T.; Tucker, C.; Los, S.; Birdsey, R.; Jenkins, J.C.; Field, C.; Holland, E. Satellite-derived increases in net primary productivity across North America, 1982-1998. Geophys. Res. Lett. 2002, 29. [CrossRef]

90. Feng, X.; Liu, G.; Chen, J.M.; Chen, M.; Liu, J.; Ju, W.M.; Sun, R.; Zhou, W. Net primary productivity of China's terrestrial ecosystems from a process model driven by remote sensing. J. Environ. Manag. 2007, 85, 563-573. [CrossRef] [PubMed]

91. Gao, Y.N.; Yu, G.R.; Zhang, L.; Lli, M.; Huang, M.; Wang, Q.F. The changes of net primary productivity in Chinese terrestrial ecosystem: Based on process and parameter models. Prog. Geogr. 2012, 1, 109-117.

92. Running, S.W.; Nemani, R.R.; Heinsch, F.A.; Zhao, M.S.; Reeves, M.; Hashimoto, H. A continuous satellite-derived measure of global terrestrial primary production. Bioscience 2004, 54, 547-560. [CrossRef]

93. Yuan, Q.Z.; Wu, S.H.; Zhao, D.S.; Dai, E.F.; Chen, L.; Zhang, L. Modeling net primary productivity of the terrestrial ecosystem in China from 1961 to 2005. J. Geogr. Sci. 2014, 24, 3-17. [CrossRef]

94. Schimel, D.S.; House, J.I.; Hibbard, K.A.; Bousquet, P.; Ciais, P.; Peylin, P.; Braswell, B.H.; Apps, M.J.; Baker, D.; Bondeau, A.; et al. Recent patterns and mechanisms of carbon exchange by terrestrial ecosystems. Nature 2001, 414, 169-172. [CrossRef] [PubMed]

95. Xiao, X.; Melillo, J.M.; Kicklighter, D.W.; Pan, Y.; McGuire, A.D.; Helfrich, J., III. Net Primary Production of Terrestrial Ecosystems in China and its Equilibrium Response to Changes in Climate and Atmospheric $\mathrm{CO}_{2}$ Concentration; MIT: Cambridge, MA, USA, 1996.

96. Wu, Y.L.; Wang, X.P.; Ouyang, S.; Xu, K.; Hawkins, B.A.; Sun, O.J.X. A test of BIOME-BGC with dendrochronology for forests along the altitudinal gradient of Mt. Changbai in northeast China. J. Plant Ecol. 2017, 10, 415-425. [CrossRef]

97. Sun, Q.L.; Li, B.L.; Zhang, T.; Yuan, Y.C.; Gao, X.Z.; Ge, J.S.; Li, F.; Zhang, Z.J. An improved BIOME-BGC model for estimating net primary productivity of alpine meadow on the Qinghai-Tibet Plateau. Ecol. Model. 2017, 350, 55-68. [CrossRef]

98. Raich, J.W.; Rastetter, E.B.; Melillo, J.M.; Kicklighter, D.W.; Steudler, P.A.; Peterson, B.J.; Grace, A.L.; Moore, B.; Vorosmarty, C.J. Potential net primary productivity in South-America-Application of a global-model. Ecol. Appl. 1991, 1, 399-429. [CrossRef] [PubMed]

99. Mcguire, A.D.; Joyce, L.A.; Kicklighter, D.W.; Melillo, J.M.; Esser, G.; Vorosmarty, C.J. Productivity response of climax temperate forests to elevated-temperature and carbon-dioxide-A North-American comparison between 2 global-models. Clim. Chang. 1993, 24, 287-310. [CrossRef]

100. McGuire, A.; Melillo, J.; Kicklighter, D.; Pan, Y.; Xiao, X.; Helfrich, J.; Moore III, B.; Vorosmarty, C.; Schloss, A. The role of the nitrogen cycle in the global response of net primary production and carbon storage to doubled $\mathrm{CO}_{2}$. Glob. Biogeochem. Cycle 1998, 12, 345-360.

101. Huntzinger, D.N.; Post, W.M.; Wei, Y.; Michalak, A.M.; West, T.O.; Jacobson, A.R.; Baker, I.T.; Chen, J.M.; Davis, K.J.; Hayes, D.J.; et al. North american carbon program (NACP) regional interim synthesis: Terrestrial biospheric model intercomparison. Ecol. Model. 2012, 232, 144-157. [CrossRef]

102. Raczka, B.M.; Davis, K.J.; Huntzinger, D.; Neilson, R.P.; Poulter, B.; Richardson, A.D.; Xiao, J.F.; Baker, I.; Ciais, P.; Keenan, T.F.; et al. Evaluation of continental carbon cycle simulations with North American flux tower observations. Ecol. Monogr. 2013, 83, 531-556. [CrossRef]

103. Yuan, W.P.; Cai, W.W.; Xia, J.Z.; Chen, J.Q.; Liu, S.G.; Dong, W.J.; Merbold, L.; Law, B.; Arain, A.; Beringer, J.; et al. Global comparison of light use efficiency models for simulating terrestrial vegetation gross primary production based on the LaThuile database. Agric. For. Meteorol. 2014, 192, 108-120. [CrossRef]

104. Yuan, W.; Cai, W.; Liu, S.; Dong, W.; Chen, J.; Arain, M.A.; Blanken, P.D.; Cescatti, A.; Wohlfahrt, G.; Georgiadis, T.; et al. Vegetation-specific model parameters are not required for estimating gross primary production. Ecol. Model. 2014, 292, 1-10. [CrossRef]

105. Malmstrom, C.M.; Thompson, M.V.; Juday, G.P.; Los, S.O.; Randerson, J.T.; Field, C.B. Interannual variation in global-scale net primary production: Testing model estimates. Glob. Biogeochem. Cycle 1997, 11, 367-392. [CrossRef]

106. Ichii, K.; Matsui, Y.; Yamaguchi, Y.; Ogawa, K. Comparison of global net primary production trends obtained from satellite-based normalized difference vegetation index and carbon cycle model. Glob. Biogeochem. Cycle 2001, 15, 351-363. [CrossRef]

107. Piao, S.L.; Fang, J.Y.; Chen, A.P. Seasonal dynamics of terrestrial net primary production in response to climate changes in china. Acta Bot. Sin. 2003, 45, 269-275. 
108. Fang, J.Y.; Chen, A.P.; Peng, C.H.; Zhao, S.Q.; Ci, L. Changes in forest biomass carbon storage in china between 1949 and 1998. Science 2001, 292, 2320-2322. [CrossRef] [PubMed]

109. Dong, J.R.; Kaufmann, R.K.; Myneni, R.B.; Tucker, C.J.; Kauppi, P.E.; Liski, J.; Buermann, W.; Alexeyev, V.; Hughes, M.K. Remote sensing estimates of boreal and temperate forest woody biomass: Carbon pools, sources, and sinks. Remote Sens. Environ. 2003, 84, 393-410. [CrossRef]

110. Asner, G.P.; Nepstad, D.; Cardinot, G.; Ray, D. Drought stress and carbon uptake in an amazon forest measured with spaceborne imaging spectroscopy. Proc. Natl. Acad. Sci. USA 2004, 101, 6039-6044. [CrossRef] [PubMed]

111. Fang, J.Y.; Yang, Y.H.; Ma, W.H.; Mohammat, A.; Shen, H.H. Ecosystem carbon stocks and their changes in China's grasslands. Sci. China Life Sci. 2010, 53, 757-765. [CrossRef] [PubMed]

112. Chen, T.T.; Peng, L.; Liu, S.Q.; Wang, Q. Spatio-temporal pattern of net primary productivity in Hengduan Mountains area, China: Impacts of climate change and human activities. Chin. Geogr. Sci. 2017, 27, 948-962. [CrossRef]

113. Melillo, J.M.; Mcguire, A.D.; Kicklighter, D.W.; Moore, B.; Vorosmarty, C.J.; Schloss, A.L. Global climate-change and terrestrial net primary production. Nature 1993, 363, 234-240. [CrossRef]

114. Piao, S.L.; Ciais, P.; Huang, Y.; Shen, Z.H.; Peng, S.S.; Li, J.S.; Zhou, L.P.; Liu, H.Y.; Ma, Y.C.; Ding, Y.H.; et al. The impacts of climate change on water resources and agriculture in China. Nature 2010, 467, 43-51. [CrossRef] [PubMed]

115. Yihui, D.; Guoyu, R.; Guangyu, S.; Peng, G.; Xunhua, Z.; Panmao, Z.; De'er, Z.; Zongci, Z.; Shaowu, W.; Huijun, W. China's national assessment report on climate change (i): Climate change in China and the future trend. Adv. Clim. Chang. Res. 2007, 3, 1-5.

116. Tao, B. Study on the Net Primary Productivity and Net Ecosystem Productivity of China's Land Ecosystem; Institute of Geographic Sciences and Natural Resources Research, CAS: Beijing, China, 2003. (In Chinese)

(C) 2018 by the authors. Licensee MDPI, Basel, Switzerland. This article is an open access article distributed under the terms and conditions of the Creative Commons Attribution (CC BY) license (http:/ / creativecommons.org/licenses/by/4.0/). 